ks. Szymon Tracz

Uniwersytet Papieski Jana Pawła II w Krakowie

\title{
Widzialny znak niewidzialnej łaski. Tzw. komplet żywiecki w skarbcu katedry na Wawelu w świetle badań źródłowych i ikonograficznych
}

Spośród niezwykle cennych tekstyliów przechowywanych w skarbcu katedry na Wawelu wyjątkowe miejsce zajmuje garnitur składający się z ornatu i dwóch dalmatyk, określany jako tzw. komplet żywiecki (ornat - nr inw. KKK tk/334 [il. 1-2], dalmatyka ze sceną Komunii świętej - KKK tk/334A [il. 3], dalmatyka ze sceną Spowiedzi - KKK 334B) [il. 4] ${ }^{1}$, który jest świadectwem bardzo wysokiej kultury religijnej na styku średniowiecza i doby nowożytnej w Małopolsce. Paramenty pochodzą z kościoła parafialnego Narodzenia NMP w Żywcu, będącego obecnie konkatedrą diecezji bielsko-żywieckiej². Komplet w latach 20. wieku XX został złożony w depozyt do Muzeum Narodowego w Krakowie przez ks. Jana Sadke (zm. 1940) ${ }^{3}$,

1. Zabytki sztuki w Polsce. Inwentarz topograficzny, t. 3, Powiat żywiecki. Województwo krakowskie, red. J. Szablowski, Warszawa 1948, s. 248-249, il. 236-240; B. Biedrońska-Słota, Ornat i dwie dalmatyki (II/207), w: Wawel 10oo-20oo. Skarby archidiecezji krakowskiej, t. 2, Katalog, red. J. A. Nowobilski, Kraków 2000, s. 216-217, il. 629. W tym miejscu pragnę podziękować za życzliwość i okazaną pomoc ks. prałatowi Zdzisławowi Sochackiemu - proboszczowi Parafii Archikatedralnej na Wawelu oraz pani mgr Barbarze Kalfas za konsultacje i cenne wskazówki naukowe w trakcie prowadzenia kwerendy.

2. Kościół parafialny pw. Narodzenia NMP w Żywcu został podniesiony do godności konkatedry na mocy bulli papieża Jana Pawła II Totus tuus Poloniae populus z 25 III 1992, reorganizującej strukturę administracyjną Kościoła w Polsce.

3. Niestety ani w Archiwum Parafialnym w Żywcu, ani w Kurii Metropolitalnej w Krakowie nie zachowały się stosowne dokumenty odnoszące się do kompletu żywieckiego. 
ówczesnego proboszcza żywieckiego, skąd w roku 1927 dyrektor Muzeum Narodowego w Krakowie Feliks Kopera przekazał go do skarbca katedry na Wawelu ${ }^{4}$. Po raz pierwszy zespół stał się przedmiotem szczególnego zainteresowania ks. Tadeusza Kruszyńskiego, który poświęcił mu w roku 1927 jedyne jak dotąd monograficzne opracowanie Ornat $i$ dalmatyki z Żywca $i$ ich holandzkie pochodzenie ${ }^{5}$. Ten wybitny znawca tkanin liturgicznych jako miejsce uszycia zespołu z włoskich altembasów wskazał Flandrię, określając czas jego powstania na ok. rok 1525. Projekt haftów atrybuował Lucasowi van Leyden (zm. 1533), co do tej pory jest powszechnie przyjmowane. Badacz w swoim opracowaniu zaproponował także rekonstrukcję pierwotnego wyglądu przerabianego w ciągu wieków ornatu oraz przywołał inne znane mu przykłady haftów z podobną dekoracją, jednakże nie przeprowadził szerszej kwerendy archiwalnej i analizy ikonograficznej całego zespołu. Ustalił jedynie, że w źródłach komplet jest uchwytny w Żywcu dopiero od ok. roku 1840. Ponadto Kruszyński odniósł się do haftów z kompletu żywieckiego, analizując dekorację hafciarską ornatu Piotra Kmity w zbiorach skarbca katedry krakowskiej ${ }^{6}$. Na podstawie ustaleń tego badacza przygotowano opis zamieszczony w Inwentarzu zabytków sztuki dla dawnego powiatu żywieckiego z roku 1948, powstałego pod kierunkiem Jerzego Szablowskiego ${ }^{7}$.

Powszechnie przyjęte ustalenia Kruszyńskiego w krótkich notach przywołały Beata Biedrońska-Słota w roku 2000 w katalogu wystawy jubileuszowej Wawel 10oo-20oo ${ }^{8}$ oraz Barbara Kalfas w katalogu towarzyszącym wystawie zorganizowanej w dniach 1 czerwca - 4 września 2011 r. w Pałacu Królewskim w Madrycie z okazji objęcia przez Polskę prezydencji w Unii

4. F. Kopera, Muzeum Narodowe w Krakowie. Wybór i opis cenniejszych zabytków, Kraków 1923, s. 10, nr 28-31; B. Biedrońska-Słota, Ornat i dwie dalmatyki..., dz. cyt., s. 216; B. Kalfas, Ornat $i$ dalmatyki z tzw. kompletu żywieckiego, w: Polonia - tesoros y colecciones artísticas. 1 junio - 4 septembre 2011 Palacio Real de Madrid, ed. B. Biedrońska-Słota, Patrimonio Nacional, Muzeum Narodowe w Krakowie 2011, s. 78 .

5. T. Kruszyński, Ornat i dalmatyki z Żywca i ich holandzkie pochodzenie, Kraków 1927.

6. T. Kruszyński, Skarbiec katedry wawelskiej i Muzeum Metropolitalne, z. 6, Ornat Piotra Kmity i ołtarz św. Antoniego fundacji Kmitów w Katedrze wawelskiej, Kraków 1930, s. $49-67$.

7. Zabytki sztuki w Polsce..., dz. cyt., s. 248-249, il. 236-240.

8. B. Biedrońska-Słota, Ornat $i$ dwie dalmatyki..., dz. cyt., s. 216-217, il. 629 . 
Europejskiej9. W obu przypadkach znalazły się informacje dotyczące materiału i techniki wykonania kompletu, z podkreśleniem wyjątkowego charakteru artystycznego dekorujących go haftów, oraz omówiono przeróbki i reparacje, które być może miały miejsce w wieku XVIII. Ponadto pierwsza z badaczek niedokładnie przytoczyła informację, jakoby Kruszyński wiązał fundację kompletu z królową Konstancją (zm. 1631), żoną króla Zygmunta III Wazy (zm. 1632), która w roku 1628 nabyła dobra żywieckie ${ }^{10}$. Natomiast Kalfas w oparciu o pobieżną kwerendę archiwalną wyraziła przypuszczenie, iż fundatorem zespołu mógł być właściciel dóbr żywieckich - Wawrzyniec Komorowski (zm. 1550), sekretarz króla Zygmunta I Starego (zm. 1548), inicjator i główny fundator przebudowy kościoła w Żywcu w latach 1515-1542 ${ }^{11}$. Z kolei Natalia Krupa w pracy opublikowanej w roku 2013, poświęconej włoskim tkaninom aksamitnym z wieku XV i XVI w zabytkowych tekstyliach w skarbcu katedry na Wawelu, nie zajmując się samymi haftami, skupiła się na określeniu rodzaju tkanin, miejsca ich pochodzenia oraz wskazała analogiczne zachowane altembasy, a także podjęła próbę rekonstrukcji całego wzoru dekorującego tkaniny ${ }^{12}$.

Składający się z ornatu (dł. 123 cm, szer. $70 \mathrm{~cm}$ ) [il. 1-2] i dwóch dalmatyk (dł. 111 cm, szer. u spodu 93 cm, pod rękawami 106 cm, szer. rękawów $30 \mathrm{~cm}$ ) [il. 3-4] garnitur żywiecki uszyto z kilku różnych fragmentów ciemnoczerwonego altembasu broszowanego o zbliżonym wzorze. W celu uzyskania efektu reliefowej, trójwymiarowej materii zastosowano strzyżenie aksamitu na dwóch wysokościach. Aksamit jest cyzelowany, a w partiach tła lansowany nicią złotą na duszy jedwabnej, wiązanej splotem rządkowym. Zasadniczym motywem wzoru jest stylizowany kwiat granatu na tle

9. B. Kalfas, Ornat i dalmatyki z tzw. kompletu żywieckiego..., dz. cyt., s. 78-79, il. I. 9-10, s. 104-105.

10. B. Biedrońska-Słota, Ornat i dwie dalmatyki..., dz. cyt., s. 217. W rzeczywistości Kruszyński zapisał: „Istnieje w Żywcu przekonanie, niczym zresztą nie uzasadnione, że nasz ornat i dalmatyki są darem królowej Konstancji. Tradycja chętnie łączy zawsze cenniejsze zabytki z wysoko postawionymi osobami, lecz ściegi lśniące delikatnym mistycznym blaskiem burgundzkiego haftu nie odpowiadały upodobaniom ani skończonego już u nas w owych latach odrodzenia, ani tem mniej zaczynającego się baroku, tak że nie byłby to wcale dar królewski dla kościoła" - T. Kruszyński, Ornat i dalmatyki..., dz. cyt., s. 7-8.

11. B. Kalfas, Ornat i dalmatyki z tzw. kompletu żywieckiego..., dz. cyt., s. 78-79.

12. N. Krupa, Włoskie tkaniny aksamitne z XVi XVI wieku w zabytkowych tekstyliach ze skarbca katedry na Wawelu, Kraków 2013, s. 117, 137, 260-264, 286-287; s. 315, rys. 4 i s. 327 , rys. 16 . 


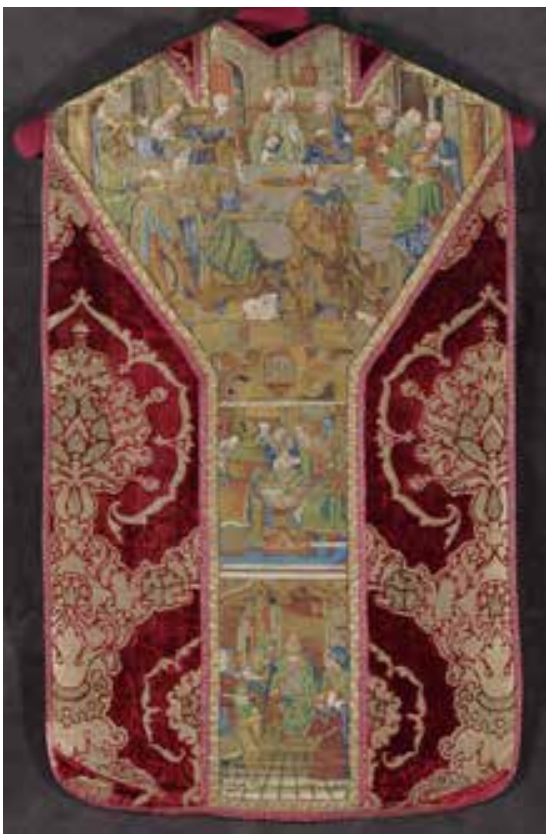

1. Tył ornatu z tzw. kompletu żywieckiego, projekt haftu Lucas van Leyden, Flandria, ok. 1525, skarbiec katedry na Wawelu (fot. ks. P. Guzik) palmety w ujęciu pięciolistnej róży i stosunkowo gruba, esowato wygięta łodyga, lamowana z dwóch stron delikatną listwą. Jej wnętrze wypełnia spiralnie opleciona akantowym listowiem smuklejsza łodyżka, zakończona kwiatowym pierścieniem. Elementy wzoru są broszowane nicią srebrną (nić jedwabna z oplotem metalowym z blaszki srebrnej). Zastosowany w obszyciu galon został wykonany w formie haftu kładzionego na podwleczeniu ze sznurka nicią z oplotem metalowym (blaszka srebrna złocona na rdzeniu jedwabnym). Z kolei użyty bordowy pasamon jest jedwabny, lansowany nicią złotą (blaszka srebrna złocona na rdzeniu jedwabnym). W całym zespole zastosowano wtórną jedwabną taftę jako ciemnoczerwoną podszewkę ornatu i niebieską w dalmatykach ${ }^{13}$. Najprawdopodobniej w epoce baroku dostosowano krój ornatu do panującej wówczas mody i obcięto jego boki oraz skrócono przód, zapewne pozbawiając go jednej sceny figuralnej, na co zwrócił uwagę Kruszyński ${ }^{14}$. Badacz ten w oparciu o zachowane inne obiekty powstałe w tym samym czasie zaproponował przekonywującą rekonstrukcje pierwotnego kształtu ornatu ${ }^{15}$, co potwierdzają także ustalenia Krupy ${ }^{16}$. Wszystko przemawia za tym, że dalmatyki zachowały się w pierwotnym kształcie ${ }^{17}$.

Komplet żywiecki $\mathrm{z}$ racji używania na przestrzeni wieków był wielokrotnie reperowany. Jednak dopiero ostatnie lata pozwoliły na przeprowadzenie gruntownej konserwacji. Bardzo trudną konserwację z próbą rekonstrukcji mocno zniszczonego haftu przodu

13. T. Kruszyński, Ornat i dalmatyki..., dz. cyt., s. 41-43; Zabytki sztuki w Polsce..., dz. cyt., s. 248-249; B. Biedrońska-Słota, Ornat i dwie dalmatyki..., dz. cyt., s. 216-217; B. Kalfas, Ornat i dalmatyki z tzw. kompletu żywieckiego..., dz. cyt., s. 78; N. Krupa, Włoskie tkaniny aksamitne..., dz. cyt., s. 260-264, 286-287; s. 315, rys. 4; s. 327, rys. 16 .

14. T. Kruszyński, Ornat i dalmatyki..., dz. cyt., s. 43.

15. T. Kruszyński, Ornat i dalmatyki..., dz. cyt., s. 44, il. 12.

16. N. Krupa, Włoskie tkaniny aksamitne..., dz. cyt., s. 315, rys. 4i s. 327 , rys. 16 .

17. N. Krupa, Włoskie tkaniny aksamitne..., dz. cyt., s. 260. 
ornatu podjęły siostry klaryski z krakowskiego konwentu św. Andrzeja, kończąc swoja pracę przy tym obiekcie po ok. 12 latach w roku 1996. Niestety mocno zniszczona scena Chrztu na przedzie ornatu została odtworzona niewłaściwie [il. 8]. Konserwację obu dalmatyk wykonano w latach 1996-2002. Przy dalmatyce ze sceną Komunii świętej (nr inw. KKK tk/334 A) pracowała Jolanta Cetnarowicz-Bis [il. 3], a przy dalmatyce ze sceną Spowiedzi (nr inw. KKK tk/334B) Barbara Kalfas [il. 4].

Paramenty zostały ozdobione cieniowanymi haftami figuralnymi wykonanymi w technice or nuè. Jak zauważyła Kalfas, „Nici złote pokrywające tło na całej powierzchni haftu, z wyjątkiem twarzy postaci, są przytrzymywane po dwie barwną, słabo skręconą przędzą jedwabną na podkładzie z dwóch warstw cienkiego lnianego płótna. Na płótnie umieszczonym bezpośrednio pod haftem naniesiono rysunek, dobrze zachowany i widoczny w miejscu ubytków. Niezwykle precyzyjny, malarski światłocień uzyskano poprzez zagęszczenie ściegów w partiach cienia i zastosowanie wielu odcieni jednej barwy. Twarze postaci traktowane indywidualnie, haftowane ściegiem satynowym bardzo cieniutkim jedwabiem, włosy i brody ściegiem rozłupanym grubszą słabo skręcaną przędzą jedwabną, detale sznureczkiem (ściegiem wodnym)"18.

Zaprezentowane hafty tworzą dwa zespoły przedstawień. Pierwszy stanowią wpisana w skrzyżowanie preteksty krzyżowej na plecach ornatu monumentalna scena Ostatniej Wieczerzy [il. 5] oraz wielofiguralne ilustracje wyobrażające udzielanie siedmiu sakramentów świętych, które rozmieszczono na ornacie i po jednej na plecach dalmatyk. Drugi składa się z całopostaciowych wizerunków świętych, umieszczonych jeden pod drugim na tle stylizowanych arkad na tylnych pasach clavi

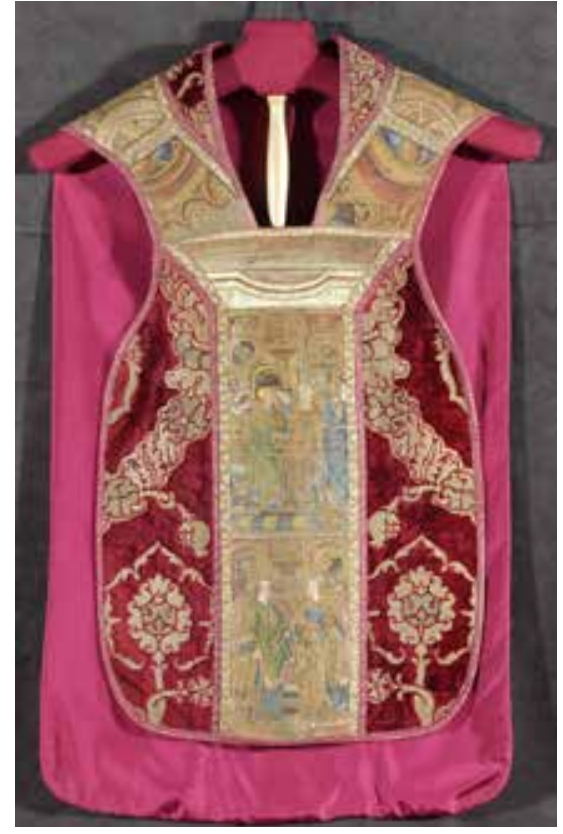

2. Przód ornatu z tzw. kompletu żywieckiego, projekt haftu Lucas van Leyden, Flandria, ok. 1525, skarbiec katedry na Wawelu (fot. ks. P. Guzik)

18. B. Kalfas, Ornat i dalmatyki z tzw. kompletu żywieckiego..., dz. cyt., s. 79 . 
dalmatyk oraz na przedzie ornatu, gdzie wyobrażono stojących obok siebie św. Wawrzyńca i św. Marię Magdalenę [il. 2]. Na dalmatyce ze sceną Komunii świętej (nr inw. KKK tk/334 A) wyhaftowano po lewej Matkę Boską z Dzieciątkiem, św. Antoniego Pustelnika, św. Jerzego oraz po prawej św. Barbarę, św. Rocha i św. Krzysztofa [il. 3], zaś na dalmatyce ze sceną Spowiedzi (nr inw. KKK tk/334B) na lewym pasie clavi znaleźli się św. Filip Apostoł, św. Mateusz Ewangelista i św. Bartłomiej Apostoł, a na prawym św. Jakub Starszy, św. Tomasz Apostoł i św. Juda Tadeusz [il. 4]. Ukazani święci są rozpoznawalni po charakterystycznych atrybutach.

Na plecach ornatu, poniżej Ostatniej Wieczerzy na kolumnie wyobrażono scenę Chrztu, określaną w starszej literaturze jako Obrzezanie lub Ofiarowanie $w$ świątyni, a jeszcze niżej Bierzmowanie [il. 1]. Natomiast na przedniej kolumnie znalazło się Małżeństwo, a poniżej wspomniani już św. Wawrzyniec i św. Maria Magdalena [il. 2]. Z tyłu na tabula pierwszej dalmatyki ukazano Komunię święta [il. 6], zaś na drugiej dalmatyce Spowiedź [il. 7]. Jeśli uznamy, że Ostatnia Wieczerza odnosi się równocześnie do Eucharystii i kapłaństwa, wtedy zabraknie nam jedynie Namaszczenia chorych, które zapewne także było przedstawione, o czym może świadczyć wyraźny fragment z przodu ornatu, będący pozostałością sceny figuralnej, widoczny powyżej sakramentu małżeństwa. Oczywiście taka interpretacja nie wyklucza możliwości istnienia osobnej sceny z przedstawieniem udzielenia święceń kapłańskich, które mogło istnieć, lecz w wyniku późniejszych przeróbek się nie zachowało.

Bez wątpienia ornat i dwie dalmatyki, określane jako komplet żywiecki, stanowiły wyjątkową ozdobę najważniejszej świątyni parafialnej na Żywiecczyźnie, jaką jest dzisiejsza konkatedra Narodzenia NMP w Żyw$\mathrm{cu}^{19}$. Zachowane archiwalia pozwalają na stosunkowo dokładną rekonstrukcję przemian zachodzących zarówno w architekturze kościoła, jak i w jego wyposażeniu w okresie staropolskim. Jest to możliwe przede wszystkim dzięki wizytacjom biskupim, począwszy od pierwszej, przeprowadzonej

19. Parafia w Żywcu aż do 1992 r. przynależała do diecezji, a później archidiecezji krakowskiej, wchodząc w skład najpierw dekanatu oświęcimskiego, a od dekretu bpa Piotra Gębickiego z 21 X 1644 do nowo powstałego dekanatu żywieckiego, zob. Sz. Tracz, Bractwa religijne $w$ dekanacie żywieckim (1598-1772), Kraków 2005, s. $46-51$. 

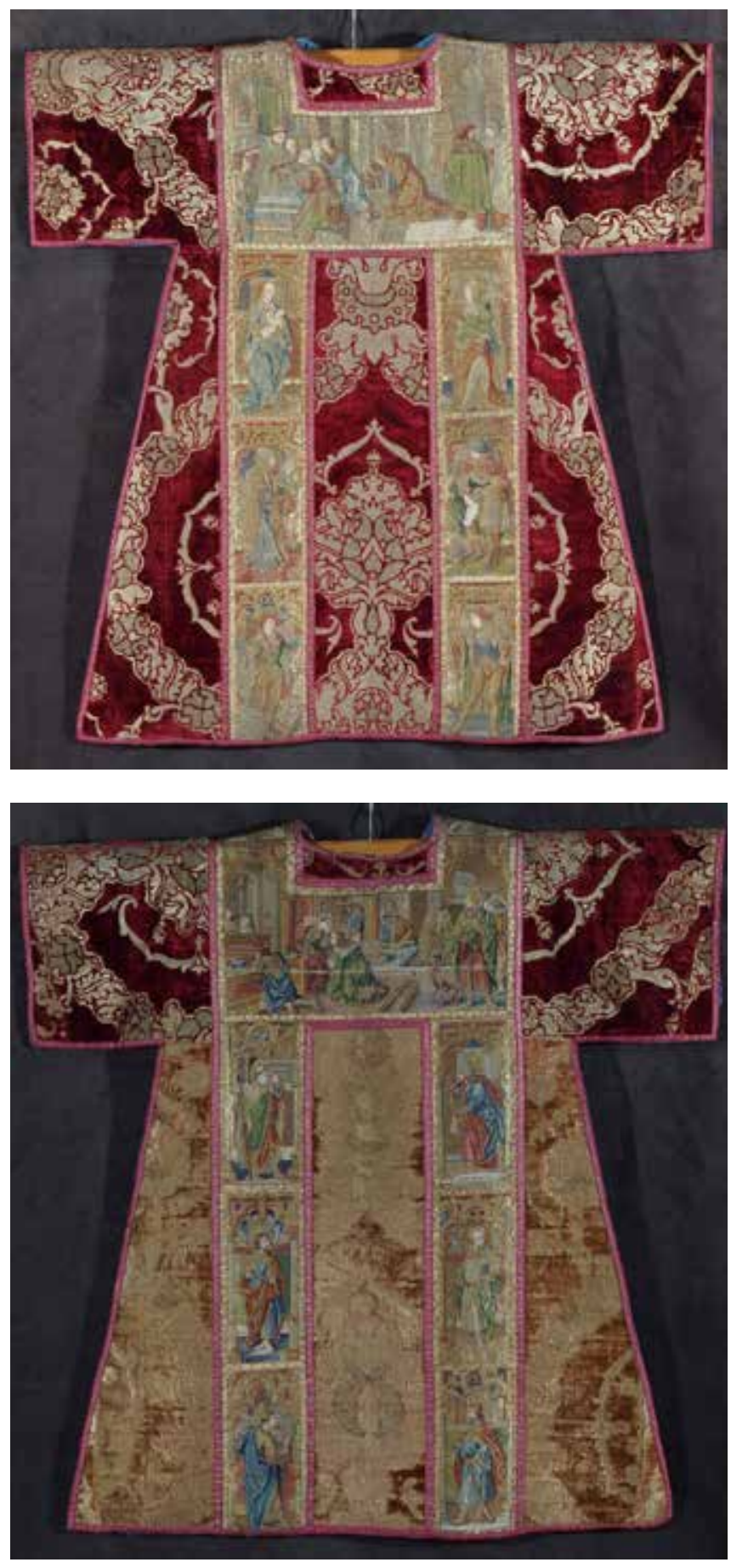

3. Dalmatyka ze sceną Komunii świętej z tzw. kompletu żywieckiego, projekt haftu Lucas van Leyden, Flandria, ok. 1525, skarbiec katedry na Wawelu (fot. ks. P. Guzik)

4. Dalmatyka ze sceną Spowiedzi z tzw. kompletu żywieckiego, projekt haftu Lucas van Leyden, Flandria, ok. 1525, skarbiec katedry na Wawelu (fot. ks. P. Guzik) 


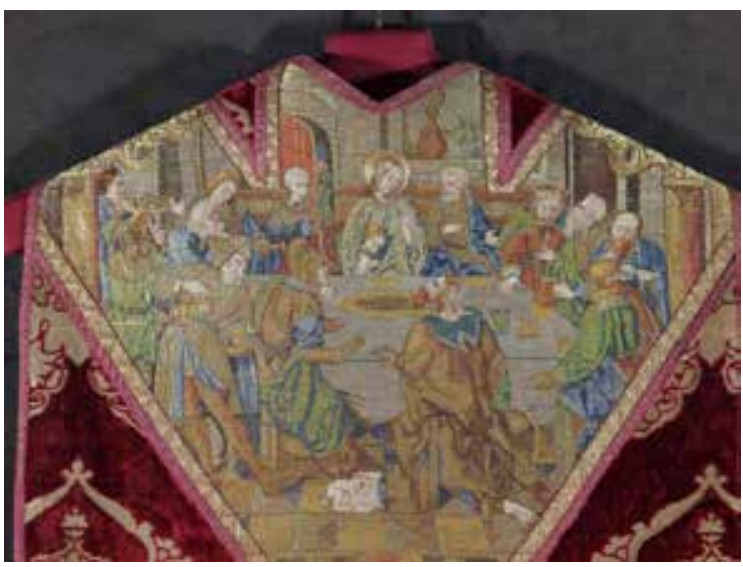

na polecenie kardynała Jerzego Radziwiłła (zm. 1600) w roku $1598^{20}$, aż do ostatniej $\mathrm{z}$ roku $1792^{21}$. Nieocenionym źródłem pomocnym w śledzeniu tychże procesów jest dzieło kronikarskie wójta żywieckiego Andrzeja Komonieckiego (zm. 1729) Chronografia albo Dziejopis żywiecki, obejmujące lata 1400-1728, z uzupełnieniem z lat $1728-1877^{22}$. Warto tu także wspomnieć o drugiej żywieckiej kronice pióra proboszcza żywieckiego ks. Franciszka Augustina Kroniki żywieckie od czasów zamierz-

5. Ostatnia Wieczerza, fragment preteksty ornatu z tzw. kompletu żywieckiego (fot. ks. P. Guzik) chłych do 1845 roku $^{23}$. Niestety zaginęły inne archiwalia z okresu staropolskiego przechowywane w Żywcu.

Przeprowadzona kwerenda archiwalna pozwoliła na jednoznaczne powiązanie kompletu z kościołem w Żywcu, co wyklucza możliwość jego późniejszego przekazania lub też ewentualnego odkupienia, jak było w przypadku innych ruchomości, co skrzętnie odnotowały źródła. Z dużym prawdopodobieństwem można

20. AVCap nr 17 - Acta visitationis exterioris Decanatuum Osviencimensis Novi Montis Zatoriennsis et Skavinensis ad Archidiaconatum Crac. Pertinentium [...] a. D. 1598, Archiwum Kurii Metropolitalnej w Krakowie.

21. AV 58 - Acta visitationis generalis decanatuum Zyvecencensis et Osviecimensis in conformitate diplomaticae dispositionis ab Excell[sisi]mo Ill[ustrissi]mo et R[everendisssi]mo Domino Floriano Amando de Janowek Janowski Episcopo Tarnovensi, Sacrae Caes[are]o-Regiae Ma[iesta]tis Consiliario ad 20 maji anni curen[tis] in personam infrapecificati delegati visitatoris gratiose emandatae quae 1 mo tabellas personarum ecclesticarum in iisdem decanatibus reperibilium, 2do prothocollum ecclesiarum, necnon 3 tio ibellos supplices quorumdam parochianorum sub aetate visitationis porectos continent. Anno 1792, Archiwum Kurii Metropolitalnej w Krakowie.

22. A. Komoniecki, Chronografia albo Dziejopis żywiecki, opr. S. Grodziski, I. Dwornicka, Żywiec 1987.

23. F. Augustin, Kroniki żywieckie od czasów zamierzchłych do 1845 roku, opr. S. Grodziski, Z. Jedynak, R. Kosiński, Z. Rączka, W. Zyzak, Żywiec-Kraków 2007. 
przypuszczać, że komplet, mimo braku konkretnego opisu dekoracji jest po raz pierwszy wzmiankowany w Żywcu przez zapis z wizytacji kard. Jerzego Radziwiłła z roku 1598, gdzie jest mowa, iż na wyposażeniu kościoła jest czerwony ornat i dwie dalmatyki wykonane z czerwonego strzyżonego altembasu przetykanego złotem ${ }^{24}$. Bardziej precyzyjnie o komplecie wyraża się zapis z wizytacji bpa Mikołaja Oborskiego z roku 1658, gdzie w grupie wymienianych ornatów czerwonych na czwartej pozycji czytamy: "Zlotoglowowy czerwony staroświeckiej roboty y materie na nim krzyż hawtowany zlotem na którym są historie septem sacramentum", zaś przy wyliczaniu dalmatyk na drugim miejscu zapisano: "Czerwonych zlotoglowowych na których po dwie kolumne w tyle haftowane różne osoby"25. Ciekawe jest, iż w późniejszych wizytacjach zespół ten nie jest już osobno wymieniany, mimo że inne ornaty znajdujące się w zakrystii kościoła są opisywane z podaniem istotnych szczegółów, jak np. zdobiący je wzór lub przedstawienia ${ }^{26}$. Być może wcześniej interesujący nas komplet znalazł się w grupie paramentów liturgicznych z kościoła żywieckiego zastawionych w styczniu roku 1623 u rodziny Rylskich herbu Ostoja przez Mikołaja Komorowskiego (zm. 1633), wykupionych 4 marca 1623 r. przez królową Konstancję. Wśród odzyskanych przedmiotów Komoniecki wymienia np. ornat haftowany

24. AVCap nr 17, k. 28-28v.

25. AVCap 46 - Visitatio Oswicimensis Decanatus a Perill[ust]ri ac Reverendissimo Domino Nicolao Oborski Dei et Apstolicae Sedis Gra[ti]ae Episcopo Laodicen[sis], Sufraganes, Archdiacono et Oficiali Generali Cracoviensi Anno D[omi]ni MDCLVIII Die XX Novembris, inhoata et subseguentibus diebus peracta, Archiwum Kurii Metropolitalnej w Krakowie, s. 222-223.

26. Jako przykład można przywołać ornat biały z haftem zdobionym perłami, przedstawiający na tylnej kolumnie Koronację NMP przez Trójcę Święta, poniżej postać św. Mikołaja oraz herb Komorowskich Korczak, o którym wspominają dwie wizytacje biskupie z r. 1709 i 1748: AV 16 - Visitatio ecclesiarum decanatuum Zathoriensis et Oswiecimensis et Zywecensis per Perillustrem olim R[evere]ndum Dominum Remigium Suszycki, can[oni]cum Cra[coviensem], specialiter deputatum, anno 1707-1709 expedita et peracta, Archiwum Kurii Metropolitalnej w Krakowie, k. 96; AV 34 - Summarium seu descripto status ecclesiarum, omnium parochorum korundem in decanatu Zyvecensis consistentium ex speciali mandato Celsissimi Illustrissimi et Reverendissimi Domini, D[Omi]ni Andrea Stanislai Kostka in Załuskie Załuski, Dei et Apostolicae Sedis episcopi Cracoviensis, ducis Severiae, per me Antonium Franciscum de Brzezie Lanckoronski, canonicum Gnesnensem, praepositum Osvecimensem, anno D[omi]ni millesimo septingentesimo quadragesimo octavo, visitatorum hoc in volumine comprehensum, Archiwum Kurii Metropolitalnej w Krakowie, k. 77 r., a także mówi o nim Andrzej Komoniecki, zob. A. Komoniecki, Chronografia..., dz. cyt., s. 391. 
perłami ${ }^{27}$. Ornat i dalmatyki wraz z innymi tekstyliami zostały szczęśliwie uratowane z wielkiego pożaru fary żywieckiej (2 VIII 1711) ${ }^{28}$. Sam komplet kronikarz wymienia dopiero w zamieszczonym w Dziejopisie żywieckim inwentarzu, sporządzonym w roku 1713 na polecenie biskupa krakowskiego Kazimierza Łubieńskiego (zm. 1719), tuż po śmierci proboszcza żywieckiego ks. Krzysztofa Anderskiego (zm. 4 II 1713). Inwentarz wykonał rodzony brat kronikarza - ks. Jan Komoniecki (1716), proboszcz z niedalekiej Milówki² ${ }^{29}$ O samym ornacie, wymienionym na pierwszym miejscu, Komoniecki pisze tak: „Ornat czerwony aksamitny złotogłowowy z kolumną albo krzyżem wielkim, staroświecki, na którym osoby hawtowane Coena Dominii cum misteriis, tak z przodku jako i z tyłu osoby rzezane, lite, podszyty płótnem błękitnym. Do niego stuła i manipularz"30. Natomiast w spisie dalmatyk interesujące nas szaty określono w następujący sposób: „Para piąta złotogłowowa czerwona z kolumnami z tyłu, hawtowana złotem, z różnymi osobami, bogata"31. Następną pewną informację podaje w swoim opracowaniu Kruszyński, powołując się na nieznany nam dziś spisany po niemiecku

27. A. Komoniecki, Chronografia..., dz. cyt., s. 138-139.

28. F. Augustin, Kroniki żywieckie..., dz. cyt., s. 544; Pożar szczegółowo opisuje A. Komoniecki, Chronografia..., dz. cyt., s. 353-359.

29. Być może Andrzej Komoniecki pomagał swemu bratu przy sporządzaniu tego inwentarza i dlatego został on zamieszczony w jego kronice - A. Komoniecki, Chronografia..., dz. cyt., s. 382-383.

30. A. Komoniecki, Chronografia..., dz. cyt., s. 389 .

31. A. Komoniecki, Chronografia..., dz. cyt., s. 393. W następnych latach komplet nie jest już wzmiankowany, chyba że odnosi się do niego zapis w wizytacji bpa Andrzeja Stanisława Kostki Załuskiego z r. 1748, w którym czytamy, że na stanie w drewnianym kościele filialnym Przemienienia Pańskiego w Żywcu był: „Drugi ornat czerwony poładamaszkowy staroświecki, na którym kolumna z osobami tkanemi cum omnibus requistis" - por. AV 34, k. 88v. Znamienne jest, że w zamieszczonym w tej wizytacji spisie ornatów, będących na stanie skarbca kościoła parafialnego, wyliczone są i w miarę szczegółowo opisane poszczególne grupy ornatów, ale nie ma tam mowy o ornacie z interesującego nas zestawu. Natomiast przywołany zapis wyraźnie mówi o istnieniu ornatu czerwonego, „staroświeckiego", wykonanego z póładamaszku i zdobionego kolumną z przedstawionymi postaciami tkanymi, co możemy rozumieć jako „haftowanymi". Ponadto do ornatu przynależały stuła, manipularz i najprawdopodobniej velum, co mogłoby być zgodne z zapisem wizytacji z r. 1658, która także zwraca uwagę, że ornat był "staroświecko robiony" oraz że był „cum omnibus requistis". Oczywiście mogła zaistnieć taka sytuacja, że na jakiś czas do niedalekiego kościoła filialnego przeniesiono sam ornat, co było powszechnie spotykaną praktyką, gdyż był on już niemodny albo mógł być podniszczony. Ale równocześnie zapis ten może się odnosić do całkowicie innego paramentu, o czym może świadczyć określenie tkaniny z której został wykonany jako póładamaszkowej. 
inwentarz Kirchen - Inwentar Pfarre in der Stadt Żywiec Wadowicer Kreises z ok. roku 1840, w którym szczegółowo opisano zarówno ornat, jak i obie dalmatyki, identyfikowane za pomocą ukazanych na nich przedstawień ${ }^{32}$. Kolejne informacje związane są już z przekazaniem zespołu w okresie międzywojennym najpierw do Muzeum Narodowego w Krakowie, a potem do skarbca katedry na Wawelu, gdzie pozostaje do dziśs ${ }^{33}$.

W swoim opracowaniu poświęconym kompletowi żywieckiemu Kruszyński, szukając ewentualnego fundatora zespołu, wyklucza niczym nieuzasadnione przekonanie funkcjonujące w lokalnej tradycji, iż mógłby to być dar królowej Konstancji ${ }^{34}$. Opinia autora wydaje się bardzo słuszna, ponadto związku z królową Konstancją nigdzie nie odnotowuje Komoniecki, który w swojej kronice bardzo precyzyjnie omawia zasługi oraz dary, jakie królowa przekazała kościołom na Żywiecczyźnie ${ }^{35}$.

Kruszyński, zgodnie z ówczesnym stanem wiedzy, sugeruje iż fundatorem kompletu żywieckiego mógł być właściciel Żywca Krzysztof Komorowski (zm. 1608), który miał podarować królowi Zygmuntowi Augustowi (zm. 1572) arras zdobiony białym orłem oraz herbem Korczak ${ }^{36}$.

32. „Messgewändern und Ornaten. Von rother Farbe. Ornat - die Seiten sammt Manipel auf goldenen Lamagrunde mit einem rothseidenen, mit Gold ausgenähten Sammt: Dessain. Die Columne ist Kreutz förmig reichlich mit Gold durchnäht, mit der Darstellung des h. Abendmahls und andern h. Gesichten - mit goldenen Tressen, die Seiten in rothseidene Bändern eingefasst - das Unterfutter von Leinwand stark abgenutzt. Schätzungswerh in Con. Münze fr. 25 [Dopisek ,jako antyk do skarbca" r. 1872]. Dalmatiken, deren Rücken ist fünf Felder oder Streifen getheilt, wovon deren nämlich die ausserssten und die mittlere von rothen mit grossen echtgoldenen mit unter angebrachten Verzierungen versehen sind. Die zwei mittlere oben vereinigten Columnen enthalten zwei grössere (Bilder?), das Sacrament der Busse und des Altars, dann 12 kleinere einzeln verschiedene Heiligen mit echten Gold gestickten Bilder. Die vorderen Columnen sind 3 Feldern getheilt, von eben denselben Sammtstoffe, wie die hintern Seiten Columnen, in welchen sich eben keine golden Verzierungen befinden. Der Rücken der einen ist ganz abgeschossen [?]. Die Columnen sind mit einer rothseidenen, mit Gold durchwirkten Bande, die Seiten eben mit gleichen Franzen umgeben. Das Unterfutter ist von blauer Leinwand. Schätzung in Con. Münze fr. 40", T. Kruszyński, Ornat i dalmatyki..., dz. cyt., s. 7.

33. F. Kopera, Muzeum Narodowe w Krakowie..., dz. cyt., s. 10.

34. T. Kruszyński, Ornat i dalmatyki..., dz. cyt., s. 7-8.

35. A. Komoniecki, Chronografia..., dz. cyt., s. 142-150, 154-161.

36. W rzeczywistości fundatorem arrasu z herbem Korczak nie był Krzysztof Komorowski lecz dworzanin króla Zygmunta Augusta, starosta horodelski Krzysztof Krupski (zm. 1566), który w r. 1560 zamówił wspomnianą tapiserię w Brukseli u Antona Leyniersa, por. M. Piwocka, Arrasy z groteskami, w: J. Szablowski, 


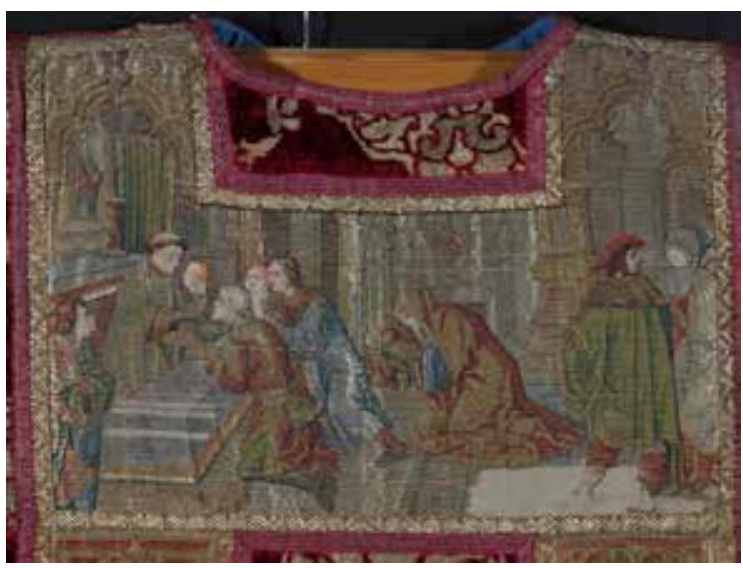

Ornat i dalmatyki mieliby dla niego zakupić w którymś z miast niderlandzkich z rąk prywatnych pośrednicy, którzy zamawiali wspomniany arras w Brukseli. Sam zaś komplet miałby ocaleć przed zniszczeniem z rąk protestantów ${ }^{37}$. Ta propozycja nie jest jednak przekonywująca. Kalfas zwróciła uwagę, że fundatorem ornatu i dwóch dalmatyk mógł być właściciel dóbr żywieckich Wawrzyniec Komorowski (zm. 1550), sekretarz króla Zygmunta I Starego (zm. 1548), finansujący w latach

6. Komunia święta, fragment tabuli dalmatyki z tzw. kompletu żywieckiego (fot. ks. P. Guzik)
1515-1542 przebudowę i nowe wyposażenie kościoła parafialnego w Żywcu ${ }^{38}$. Być może współfundatorem szat był jego brat Jan Komorowski (zm. 1566), kasztelan połaniecki, który to, jak zaświadcza kronikarz żywiecki, „ten kościół wespół z Wawrzyńcem bratem wymurował i wiele dostatnich ozdób kościołowi temu zostawił, jako to srebrną wielką monstrancję [...], krzyż wielki, kielichów, ornatów etc."39. Fundatorem mógł być również syn Jana Komorowskiego - Jan Spytek Komorowski (zm. 1585), podczaszy na dworze Katarzyny (zm. 1572), żony króla Zygmunta Augusta, za czym może przemawiać następująca zapiska Komonieckiego: „Roku tegoż [1583] pan Jan Spytek Komorowski, podczaszy, sprawił kościołowi żywieckiemu aparata jedbawne czerwone z antepediami i kielich z patyną, a to wszystko dał księdzu Walentemu Korabikowi, plebanowi żywieckiemu. Co się działo we czwartek w samę wigilię świętego Jana

A. Misiąg-Bocheńska, M. Hennel-Bernasikowa, M. Piwocka, Arrasy wawelskie, Warszawa 1999, s. 337, il. 89.

37. T. Kruszyński, Ornat $i$ dalmatyki..., dz. cyt., s. 8.

38. A. Komoniecki, Chronografia..., dz. cyt., s. 68; B. Kalfas, Ornat i dalmatyki z tzw. kompletu żywieckiego..., dz. cyt., s. 78.

39. A. Komoniecki, Chronografia..., dz. cyt., s. 84 . 
Krzciciela [23. VI]"40. Wszystko jednak wskazuje, że ta fundacja dotyczy innych paramentów ${ }^{41}$.

Za fundacją Wawrzyńca Komorowskiego, zgodnie z sugestią Kalfas, zdaje się przemawiać obecność na wyeksponowanym miejscu przodu ornatu wizerunku św. Wawrzyńca, obok którego stoi św. Maria Magdalena [il. 2] ${ }^{42}$. Jednocześnie jednak należy pamiętać, iż kościół parafialny w Żywcu, konsekrowany 9 października 1545 r. przez bpa Erazma Ciołka (zm. 1546),

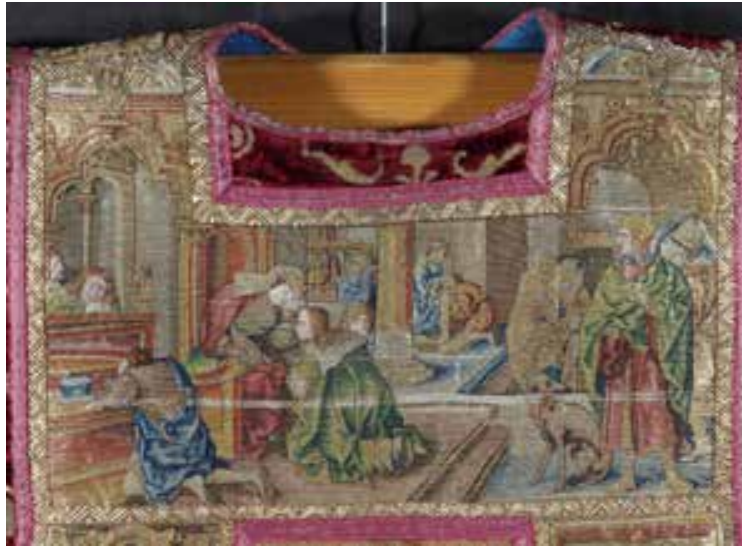
opata mogilskiego i sufragana krakowskiego, otrzymał dwa wezwania: Narodzenia NMP i św. Wawrzyńca, diakona i męczennika ${ }^{43}$. Zapewne wybór drugiego wezwania nie był przypadkowy i wiązał się z patronem

7. Spowiedź, fragment tabuli z tzw. kompletu żywieckiego (fot. ks. P. Guzik) dobroczyńcy świątyni - Wawrzyńcem Komorowskim. Związek ze św. Wawrzyńcem podkreśla także czerwony kolor paramentów, którego w liturgii używa się wyłącznie we wspomnienia męczenników (także w Niedzielę Męki Pańskiej (Palmową), Wielki Piątek i w Zesłanie Ducha Świętego) ${ }^{44}$. Co ciekawe, w samym komplecie został zminimalizowany wątek maryjny, sprowadzony tylko do przedstawienia Madonny z Dzieciątkiem na pasie clavi dalmatyki ze sceną Komunii świętej [il. 3]. Jeśli taka interpretacja byłoby zgodna z prawdą historyczną, wtedy można by ostrożnie wysnuć hipotezę, że komplet zamówiono specjalnie do Żywca, a więc mógł być

40. A. Komoniewski, Chronografia..., dz. cyt., s. 96; F. Augustin, Kroniki żywieckie..., dz. cyt., s. 502.

41. Być może jest to zapis odnoszący się do zachowanego w Żywcu czerwonego ornatu z aplikacją na tylnej kolumnie, przedstawiającej Matkę Boską z Dzieciątkiem na półksiężycu w promienistej mandorli, zob. Zabytki sztuki w Polsce..., dz. cyt., s. 249, il. 241.

42. Zob. B. Kalfas, Ornat i dalmatyki z tzw. kompletu żywieckiego..., dz. cyt., s. 78 .

43. A. Komoniecki, Chronografia..., dz. cyt., s. 68.

44. B. Nadolski, Leksykon liturgii, Poznań 2006, s. 656. 
świadomą fundacją, doskonale wpisującą się w renesansowe zmiany zachodzące w dobrach Komorowskich w pierwszej połowie wieku XVI.

Niezależnie od tego, kto był fundatorem ornatu i dwóch dalmatyk, był to bez wątpienia dar iście królewski, mogący stanowić prawdziwą ozdobę najwspanialszych europejskich katedr. Wyjątkowość żywieckiego kompletu tkwi przede wszystkim w kosztowności zastosowanego materiału, bardzo drogiego w ówczesnych realiach ekonomicznych, oraz w niezwykle precyzyjnym hafcie i bogatym, rzadko spotykanym programie ikonograficznym.

Zwyczaj ozdabiania paramentów liturgicznych przedstawieniami figuralnymi sięga wczesnego średniowiecza, a zachowane przykłady świadczą, iż były to hafty na bardzo wysokim poziomie, co można zauważyć np. na trzech górnoreńskich kapach pochodzących z benedyktyńskiego opactwa St. Blaisen w Szwarcwaldzie - pierwszej, z drugiej ćwierci wieku XII, dekorowanej scenami ze Starego i Nowego Testamentu i przedstawieniami świętych (24 przedstawienia) i drugiej, z trzeciej ćwierci wieku XIII, ze scenami z legendy św. Błażeja i Wincentego z Saragossy (23 haftowane medaliony), przechowywanych obecnie w opactwie St. Paul im Lavanttal w Karyntii, oraz trzeciej, z trzeciej ćwierci wieku XIII, dekorowanej cyklem chrystologicznym oraz scenami z legendy św. Mikołaja (47 przedstawień), znajdującej się w zbiorach Österreichisches Museum für angewandte Kunst w Wiedniu (nr inw. 9125) ${ }^{45}$. Szczególne realizacje hafciarskie powstawały w drugiej połowie wieku XIII i w wieku XIV w pracowniach angielskich w oparciu o tzw. opus anglicanum ${ }^{46}$, wywierając równocześnie znaczny wpływ na sposób dekorowania paramentów tworzonych przez cały wiek XV. Można tu przywołać m.in. kapę ze scenami pasyjnymi z lat 12901300 (Saint-Bertrand-de-Comminges, skarbiec katedralny) ${ }^{47}$, monumentalną dekorację ukazującą świętych papieży męczenników w dziewiętnastu

45. Das Tausendjährige St. Blasien 2oojähriges Domjubiläum, t. 1, Katalog, Hrsg. Ch. Römer, Karlsruhe 1983, s. 170-180, il.153-155; A. Capitanio, Casula a campana, w: San Nicola. Splendori d'arte d'Oriente e d'Occidente, ed. M. Bacci, Milano 2006, s. $328-329$, il. VI.6.

46. Szerzej to zagadnienie omawiaja m.in. L. Martini, Il piviale di Pienza e $i$ rapporti con la cultura artistica del Trecento, w: Il piviale di Pio II, ed. L. Martini, Milano 2001, s. 26-36; English Medieval Embroidery - Opus Anglicanum, ed. by C. Browne, G. Davies, M.A Michael, New Haven - London 2016 - tam też zebrana najnowsza literatura przedmiotu.

47. L. Martini, Il programma iconografico, w: Il piviale di Pio II, ed. L. Martini, Milano 2001, s. $63-64$, il. 84 . 
medalionach pokrywających pluwiale wykonane dla papieża Grzegorza X (1272-1276) w Pinacoteca Civica w Ascoli Piceno ${ }^{48}$, wspaniałe pluwiale z lat 1316 - 1320 z cyklem maryjnym i hagiograficznym Piusa II (1458-1464) (Pienza, Museo Diocesano) ${ }^{49}$ czy też kapę kardynała Gli de Albornoz z lat 13151320 z historią Maryi, apostołów i świętych (Toledo, skarbiec katedry) ${ }^{50}$. Oczywiście z tego czasu zachowały się także hafty zdobiące ornaty i dalmatyki, ale z racji na szczupłość miejsca są to realizacje skromniejsze, jak np. ornat z drugiej ćwierci wieku XIV, tzw. Chichester-Constable (Nowy Jork, Metropolitan Museum of Art) ze scenami cyklu maryjnego ${ }^{51}$. W wymienionych obiektach można wyraźnie zauważyć rozwój schematu kompozycyjnego, gdzie obramienie scen figuralnych przechodzi transformację z form owalnych do przestrzeni zamkniętych arkadami, co bezsprzecznie idzie w parze z tym samym procesem zauważalnym w kształtowaniu się dekoracji iluminowanych kodeksów.

Wraz z rozwojem technik tkackich oraz hafciarskich, poprzez zastosowanie na szeroką skalę złotych i srebrnych nici, haftowane paramenty nabrały szczególnego blasku w wieku XV w Niderlandach, ale także w Italii. Bez wątpienia doskonały przykład stanowi tutaj unikalny zespół paradnych, liturgicznych strojów i paramentów pozostających w służbie Zakonu Złotego Runa na dworze burgundzkim, przechowywany w latach 1477-1797 w Sainte Chapelle w Dijon (Wiedeń, Kunsthistorisches Museum, Schatzkammer $)^{52}$. Wspomniany komplet, powstały najprawdopodobniej w latach 1442-1451, składa się z dwóch dossale z Tronem Łaski i z Mistycznymi zaślubinami św. Katarzyny, które w architektonicznych obramowaniach otaczają prorocy i apostołowie; dalej z trzech kap z wizerunkami aniołów, świętych lub proroków, ukazanych pod arkadami wypełnionymi maswerkami o bogatym zarysie; wreszcie z dwóch dalmatyk, analogicznie do kap pokrytych siatką sześciobocznych pół z figurami świętych niewiast na jednej i świętych mężów na drugiej oraz z ornatu ukazującego na obu kolumnach,

48. G. Gagliardi, M. Piccinini Fabi, Il piviale di Ascoli, Ascoli Piceno 1990.

49. L. Martini, Il piviale in "opus anglicanum" di Pio II, w: Il piviale di Pio II, ed. L. Martini, Milano 2001, s. 15-25, il. 1-10.

50. L. Martini, Il piviale di Pienza..., dz. cyt., s. 31, il. 21.

51. L. Martini, Il piviale di Pienza..., dz. cyt., s. 29, il. 14.

52. Historię i znaczenie kompletu Zakonu Złotego Runa omawia szczegółowo m.in. A. Ziemba, Sztuka Burgundii i Niderlandów 138o-150o, t. 1, Sztuka dworu burgundzkiego oraz miast niderlandzkich, Warszawa 2008, s. 42-62, il. 20-27, 29-30, 32, tabl. $3-9$. 
przedniej i tylnej, dwie sceny epifanii Chrystusa - Chrzest w Jordanie oraz Przemienienie na Górze Tabor ${ }^{53}$. Z kolei z terenów Italii można tu przywołać hafty wykonane według projektu Antonia del Pollaiuolo w latach 14661487, ze scenami z legendy św. Jana Chrzciciela, zdobiące niegdyś ornat i dwie dalmatyki będące darem kapucynów florenckich dla baptysterium San Giovanni we Florencji (Florencja, Museo dell'Opera di Santa Maria del Fiore) ${ }^{54}$. W naszych rozważaniach są one istotne, gdyż stały się ważnym odniesieniem dla analizy stylistycznej przeprowadzonej przez Kruszyńskiego $^{55}$. Obok przywołanych przez Kruszyńskiego ornatów z kościoła św. Lebuinusa w Deventer i kościoła z holenderskiego Hoorn, według projektów Cornelisa Engelbrechtsza (zm. 1534) ${ }^{56}$, ważne miejsce zajmuje także ornat z włoskiego aksamitu przetykanego złotem z fary św. Lamberta w Erkelenz, z roku 1509 (Kolonia, Museum Schnütgen, nr inw. P 218), zdobiony Pokłonem Trzech Króli i scenami cyklu maryjnego, z fundacji gildy cieśli z Utrechtu, którego kształt haftów, ich kompozycja oraz sposób rozmieszczenia są bardzo zbliżone do przedstawień z ornatu z kompletu żywieckiego ${ }^{57}$.

Wyjątkowość paramentów z Żywca podkreśla zrealizowany program ideowy nawiązujący do udzielania sakramentów świętych ${ }^{58}$. Dzięki

53. A. Ziemba, Sztuka Burgundii i Niderlandow 1380-150o, t. 1, Sztuka dworu burgundzkiego..., dz. cyt.

54. Zob. A. Galli, The Fortune of the Pollaiuolo Brothers, w: Antonio and Piero del Pollaiuolo - "Silver and Gold, Painting and Bronze...", ed. by A. Di Lorenzo, A. Galli, Milano 2014, s. 50-56; F. Siddi, Workshop of Antonio del Pollaiuolo "Zachariah Leaving the Temple", secondo half of the fifteenth century, w: Antonio and Piero del Pollaiuolo - "Silver and Gold, Painting and Bronze...", ed. by A. Di Lorenzo, A. Galli, Milano 2014, s. 182, il. s. 183; F. Siddi, Embroidery in silk and gold thread Florence, Museo dell'Opera di Santa Maria del Fiore, w: Antonio and Piero del Pollaiuolo "Silver and Gold, Painting and Bronze...", ed. by A. Di Lorenzo, A. Galli, Milano 2014, S. $184-190$, il. s. $185,187,189,190-191$.

55. Por. T. Kruszyński, Ornat i dalmatyki..., dz. cyt., s. 22-32, il. 4-6.

56. T. Kruszyński, Ornat i dalmatyki..., dz. cyt., s. 44-46, il. 17-19.

57. Museum Schnütgen. Die liturgischen Gewänder 11.bis 19. Jahrhundert, Hrgs. G. Sporbeck, Köln 2001, s. 209-212, il. 52a-52C.

58. W teologii katolickiej sakrament jest to widzialny znak niewidzialnej łaski Chrystusa, którą wierzący otrzymują poprzez posługę Kościoła. Nie byłoby to możliwe, gdyby nie zbawcza ofiara Zbawiciela, który ustanawiając siedem sakramentów świętych, posłużył się widzialnymi znakami. Kształtującą się przez wieki naukę o sakramentach świętych po raz pierwszy w syntetyczny sposób podano w 1547 w kanonach VII sesji Soboru Trydenckiego (1545-1563), zob. Breviarium fidei. Wybór doktrynalnych wypowiedzi Kościoła, red. S. Głowa, I. Bieda, Poznań 1997, s. 356-359; Dokumenty soborów powszechnych. Tekst łaciński, polski, t. IV/1, (1511-1870), Lateran V, Trydent, Watykan I, opr. A. Baron, H. Pietras, Kraków 2007, 
definiowaniu nauki o siedmiu sakramentach za pomocą arystotelesowskiej koncepcji materii i formy ${ }^{59}$ można było wyrazić ich treść przez obrzęd liturgiczny, ten zaś był możliwy do wizualizacji za pomocą sztuk plastycznych, pomagając wiernym w zrozumieniu teologicznych treści. Dlatego też sięgano do typologii biblijnej, symbolicznych nawiązań, a wreszcie do dosłownego ilustrowania celebracji poszczególnych sakramentów, akcentując równocześnie ich źródło - Chrystusa Pana żyjącego w Kościele ${ }^{60}$. W tym miejscu należy zaznaczyć, iż z terenu Europy zachowało się tylko kilka przykładów dekorowania tkanin liturgicznych przedstawieniami siedmiu sakramentów, mimo że spotykamy realizacje takich przedstawień w innych sztukach plastycznych, zwłaszcza w kręgu piętnastowiecznej sztuki niderlandzkiej - malarstwie ściennym, witrażowym, książkowym, rzeźbie (zwłaszcza w dekoracji chrzcielnic) czy też w licznie zachowanych rzeźbionych lub malowanych retabulach ołtarzowych i na tapiseriach ${ }^{61}$.

Z zachowanych przykładów należy przede wszystkim przywołać cykl zdobiący aksamitny ornat haftowany złotem i srebrem, znajdujący się w zbiorach belgijskiej kolegiaty St. Vincent w Soignies (Zinnik) z końca wieku XV ${ }^{62}$. Ornat był kilkakrotnie przeszywany i obcinany, o czym świadczą przycięte dwa haftowane przedstawienia. Sceny zostały rozmieszczone

s. 343-365. Zob. też Dokumenty soborów powszechnych. Tekst grecki, łaciński, arabski, ormiański, polski, t. III, (1414-1445) Konstancja, Bazylea-Ferrara-Florencja-Rzym, opr. A. Baron, H. Pietras, Kraków 2007, s. 505-525.

59. Por. Dekret dla Ormian Soboru Florenckiego (1438-1445), w: Breviarium fidei..., dz. cyt., s. 356 .

60. Zagadnienie średniowiecznej ikonografii siedmiu sakramentów w kontekście przykładów z Wysp Brytyjskich, na tle zachowanych przedstawień z terenów Europy Zachodniej, z podaniem bogatej literatury przedmiotu omawia m.in. A. E. Nichols, Seeble Sings: Iconography of the Seven Sacraments 1350-1544, Oxford 1997. Zob. też B. Kerber, Sakramente, w: Lexikon der christlichen Ikonographie, t. 4, Allgemeine Ikonographie $S-Z$, Hrgs. E. Kirschbaum, Rom-Freiburg-Basel-Wien 1994, kol. 5-11.

61. Por. H. J. de Smedt, De Antwerpse retabeles en hun iconografie: een overzicht van onderwerpen en veranderingen, w: Les retables anversois XV-XVI siècles, t. 2, Essays, ed. H. Nieuwdorp, Antwerpen 1993, s. 32-35; A. E. Nichols, Seeble Sings..., dz. cyt., s. 29-89; L. Campbell, "The Seven Sacraments”, w: Roger van der Weyden in Context. Papers presented at the Seventeenth Symposium for the Study of Underdrawing and Technology in Painting held in Leuven, 22-24 October 20og, ed. by L. Campbell, J. Van der Stock, C. Reynolds, L. Watteeuw, Paris-Leuven-Walpole, MA 2012, s. 137-145.

62. Flanders in the Fifteenth Century: Art and Civilization, Catalogue of the Exhibition: Masterpieces of Flemish Art: Van Eyck to Bosch, ed. by R. Edgar, P. Coremans, Detroit-Bruges 1960, s. 334-345; A. E. Nichols, Seeble Sings..., dz. cyt., s. 41-42. 
na pretekście, gdzie wyobrażono Eucharystię, Święcenia kapłańskie oraz Ostanie namaszczenie. Przód ornatu zdobi kolumna, na której przedstawiono Chrzest, Bierzmowanie oraz Pokutę. W zespole brakuje Małżeństwa, które według Nichols zostało pominięte. Podobnie jak w komplecie żywieckim, także tutaj tłem dla przedstawień jest architektura, a poszczególne sceny wypełnia grupa kilku postaci63.

W podobny sposób zakomponowano hafty na borcie z niezachowanej już dziś kapy z ok. roku 1470, z fundacji hrabiego Giacoma de Savoia-Romont (zm. 1486), gdzie na jednym pasie ukazano Chrzest, Namaszczenie chorych i Bierzmowanie, a na drugim Kapłaństwo, Małżeństwo i Pokutę. Natomiast wyobrażenie Mszy świętej i Komunii świętej połączono z Tronem Łaski w typie Pietas Patris i zilustrowano na kapturze kapy z herbem Domu Sabaudzkiego (Berno, Bernisches Historisches Museum, inv. 308) ${ }^{64}$. Podobny zespół scen zachował się na haftach z flandryjskiej kapy z końca XV w. (Detroit, Institute of Arts), gdzie wyobrażono Bierzmowanie, Chrzest, Małżeństwo, Kapłaństwo i Ostatnie namaszczenie ${ }^{65}$.

Analizując pod względem ikonograficznym sceny udzielania sakramentów świętych przedstawione na komplecie żywieckim, łatwo zauważyć, że są one głęboko osadzone w bogatej tradycji ikonograficznej określającej sposób ukazywania kolejnego sakramentu, w oparciu o wcześniej wypracowany typ ikonograficzny, który następnie rozbudowywano najczęściej poprzez dodawanie dodatkowych postaci lub też za pomocą wprowadzania charakterystycznych szczegółów czerpanych z codziennej obserwacji życia liturgiczno-religijnego. Punktem wyjścia do budowania kolejnych kompozycji jest łatwo rozpoznawalny ów „widzialny znak”, za którym kryje się treść odnosząca się do „niewidzialnej łaski", właściwa dla poszczególnych sakramentów.

Dla chrztu elementem konstytutywnym była centralnie umieszczona chrzcielnica w kształcie kielicha, ponad którą kapłan trzyma niemowlę. Po obu jej stronach stoją rodzice oraz często rodzice chrzestni. Sakrament bierzmowania oparty był na przedstawieniu stojącego lub siedzącego biskupa, który namaszczał czoło najczęściej klęczącemu przed nim młodemu człowiekowi. Eucharystia była wyrażana jako ilustracja celebracji mszy

63. A. E. Nichols, dz. cyt., Seeble Sings...

64. T. Kruszyński, Ornat i dalmatyki..., dz. cyt., s. 20-22, il. 74-77; A. E. Nichols, Seeble Sings...,dz. cyt., s. 40-41, il. 19.

65. A. E. Nichols, Seeble Sings..., dz. cyt., s. 41. 
świętej w chwili podniesienia przez kapłana hostii po przeistoczeniu lub też w momencie udzielania komunii świętej, co znalazło się na pierwszej dalmatyce żywieckiej. W sakramencie pokuty istotnym elementem było wyobrażenie kapłana siedzącego w otwartym konfesjonale, słuchającego wyznania grzechów przez klęczącego przed nim człowieka, jak wyobraża to druga dalmatyka z Żywca. Namaszczenie chorych, najprawdopodobniej niezachowane na ornacie z kompletu żywieckiego, rozpoznawalne było po leżącym w łóżku chorym, nad którym pochyla się namaszczający go świętym olejem kapłan. Sakrament kapłaństwa przedstawiano jako siedzącego biskupa, przed którym klęczy duchowny przyjmujący z jego rąk święcenia, co czasem podkreślał gest przekazania kielicha mszalnego. Tej sceny także brakuje w analizowanym komplecie. Wreszcie w sakramencie małżeństwa istotne było podanie sobie rąk przez nowożeńców, przy asystencji duchownego ${ }^{66}$.

O ile każdy z wymienionych układów ikonograficznych występuje na paramentach z Żywca, co pozwala na jednoznaczne zidentyfikowanie sakramentów, o tyle wiele wątpliwości budzi pierwsza scena z tyłu ornatu, umieszczona pod Ostatnia Wieczerza [il. 8]. Kruszyński określił ją jako Obrzezanie lub Ofiarowanie $w$ światyni, za czym przemawia według niego obecność stojącego z lewej strony starotestamentalnego kapłana w dalmatyce i odwróconej infule na głowie. W ten sposób badacz odrzucił możliwość wyobrażenia tu Chrztu ${ }^{67}$. Biedrońska-Słota określa to przedstawienie jako Ofiarowanie $w$ światyni ${ }^{68}$, a Kalfas skłania się jednak ku tezie, iż jest to Chrzest ${ }^{69}$. Wydaje się, iż ta ostatnia interpretacja jest najbardziej właściwa, co potwierdza zestawienie tej sceny z innymi zachowanymi wyobrażeniami tego sakramentu ${ }^{70}$. W licznie zachowanych przykładach zawsze głównym elementem jest masywna chrzcielnica w kształcie kielicha. Tak też wyobrażono ją na żywieckim ornacie. Wątpliwości, które szeroko

66. A. E. Nichols, Seeble Sings..., dz. cyt., s. 185-302.

67. T. Kruszyński, Ornat i dalmatyki..., dz. cyt., s. 48-50.

68. B. Biedrońska-Słota, Ornat i dwie dalmatyki..., dz. cyt., s. 216.

69. B. Kalfas, Ornat i dalmatyki z tzw. kompletu żywieckiego..., dz. cyt., s. 78.

70. W ten sposób scenę chrztu wyobraził m.in. Roger van der Weyden na Ołtarzu Siedmiu Sakramentów z l. 1440-145 (Antwerpia, Koninklijk Museum voor Schone Kunsten) oraz ukazano ją na kilkunastu retabulach niderlandzkich powstałych w l. 1500-1544 czy też na chrzcielnicach angielskich z tego samego czasu, por. A. E. Nichols, Seeble Sings..., dz. cyt., s. 30-35, 193-206, il. 7b, 25-28, 34-40. Tak samo scenę chrztu wyobrażają omówione już wcześniej hafty, por. przypis 60-63. 
analizuje Kruszyński, były związane z bardzo złym stanem zachowania tego przedstawienia, co pokazują zdjęcia archiwalne zrobione zanim komplet opuścił Żywiec ${ }^{71}$. Dodatkowo zachowane fotografie sprzed konserwacji ornatu wskazują, iż podczas naprawy dokonano tu nadinterpretacji. Osoba konserwująca wprowadziła do sceny nieistniejącą postać o zaskakującej niebieskiej twarzy, której zarys błędnie odczytała z owalnego kształtu, wydającego się być nie tułowiem, lecz po prostu uchyloną przykrywą chrzcielnicy. Dodatkowo w czasie konserwacji nieznacznie zmieniono układ nakrycia głowy osoby z lewej strony, co Kruszyński zinterpretował już wcześniej jako nakrycie głowy starotestamentalnego kapłana, mimo że badacz miał możliwość analizy przedstawienia przed konserwacją. Rzeczywiście, mimo wcześniejszych uszkodzeń można rozpoznać, że ma ono kształt mitry biskupiej, a sposób jego przedstawienia na głowie jest właściwy dla osoby patrzącej na tę postać z boku. Zatem nic nie stoi na przeszkodzie, aby widzieć w tej scenie biskupa zanurzającego niemowlę w chrzcielnicy. Poza tym scena Chrztu bardzo dobrze wpisuje się w bogaty program ikonograficzny kompletu, tworząc z nim komplementarną całość. Wreszcie nigdzie w scenie Obrzezania czy też Ofiarowania w świątyni nie występuje ołtarz, który miałby kielichowaty kształt ${ }^{72}$. Dlatego też w tym przedstawieniu należy widzieć ilustrację chrztu.

Wyjątkowość kompletu żywieckiego pośród europejskich przedstawień siedmiu sakramentów wyraża się również w bardzo przemyślanej koncepcji prezentacji kolejnych przedstawień. Zostawiając na boku kwestię wyhaftowanych świętych, należy zwrócić uwagę, że cały cykl sakramentalny rozdzielono między trzy obiekty - ornat i dwie dalmatyki. Dzięki temu zabiegowi był on widoczny w całości tylko wtedy, gdy był używany podczas liturgii przez trzech duchownych - kapłana i dwóch diakonów. Obróceni tyłem do wiernych duchowni prezentowali trzy najważniejsze sceny całego zespołu: Ostatnia Wieczerze [il. 5], którą bez żadnych wątpliwości należy odnieść do kapłaństwa, oraz Spowiedź i Komunię święta [il. 6-7]. Taki

71. T. Kruszyński, Ornat i dalmatyki..., dz. cyt., s. 108, il. 39. Dziękuję pani Joannie Hiżyckiej za udostępnienie archiwalnych zdjęć kompletu żywieckiego znajdujących się w fototece Wojewódzkiego Urzędu Ochrony Zabytków w Krakowie.

72. Zob. Ch. A. Isermeyer, Beschneidung Christi, w: Lexikon der christlichen Ikonographie, t. 1, Allgemeine Ikonographie A-E, Hrsg. E. Kirschbaum, Rom-Freiburg-Basel-Wien 1994, kol. 271-273; E. Lucchesi Palli, L. Hoffscholte, Darbringung Jesu im Tempel, w: Lexikon der christlichen Ikonographie, t. 1, Allgemeine Ikonographie A-E, dz. cyt., kol. 473-477. 
wybór nie wydaje się przypadkowy, do czego przyjdzie się nam jeszcze odnieść. W tym miejscu warto postawić pytanie, dlaczego twórca całości wyeksponował jako najważniejszą Ostatnia Wieczerzę w pretekście ornatu?

By móc odpowiedzieć na to pytanie, należy pamiętać, iż sakramenty święte są źródłem łaski Boskiej, którą wierny otrzymuje poprzez posługę Kościoła, dzięki zbawczej ofierze Chrystusa na krzyżu, o czym była już mowa. Zatem w centrum całej doktryny katolickiej dotyczącej sakramentów są męka, śmierć i chwalebne zmartwychwstanie Jezusa Chrystusa. Dlatego też w sztuce siedem sakramentów świętych najczęściej umieszczano w kontekście zbawczej ofiary Zbawiciela, którą uosabiano za pomocą sceny Ukrzyżowania. Jako przykład takiego ujęcia można przywołać tablicę Bonifacia Ferrera z końca wieku XIV (Valencia, Museo de San Carlos), gdzie Ukrzyżowaniu towarzyszy siedem sakramentów ujętych w wieloboczne obramowania umieszczone po obu stronach krucyfiksu ${ }^{73}$. Podobną konwencję zastosował w latach 1440-1445 Rogier van der Weyden w Ołtarzu siedmiu sakramentów (Antwerpia, Koninklijk Museum voor Schone Kunsten, nr inw. 393-395), namalowanym dla Jeana Chevrota, biskupa Tournai ${ }^{74}$. To wybitne dzieło przede wszystkim podkreśla teologiczny związek zachodzący pomiędzy ofiarą Chrystusa a sakramentami oraz ich naturalną przestrzenią życia, którą jest wnętrze kościoła. Dlatego też w głównej nawie gotyckiej świątyni na pierwszym planie wyobrażono Ukrzyżowanie, zaś w głębi Mszę święta, natomiast w nawach bocznych symultanicznie przedstawiono udzielanie kolejnych sakramentów świętych, począwszy od chrztu, a na ostatnim namaszczeniu kończąc. Jak zauważył Antoni Ziemba: „Całość retabulum mówi bowiem o tym, że uczestnictwo w sakramentach wynika z wiary w transsubstancjację w najświętszym z sakramentów, w Eucharystii, w rzeczywistą przemianę chleba w ciało. Realne postacie w grupie Ukrzyżowania, zwłaszcza ciało Chrystusa, podkreślają realność obecności Chrystusa w sakramencie Eucharystii. Figury osób świętych tworzą «żywy obraz», tableau vivant. [...] Ta pozaziemska scena, urealniona we wnętrzu normalnego kościoła, oznacza, że Ciało Chrystusa, umęczone

73. A. E. Nichols, Seeble Sings..., dz. cyt., s. 20; R. Alcoy, La ricezione della pittura giottesca in Spagna, dai Bassa a Starnina, w: Giotto e il Trecento „Il più Sovrano Maestro stato in dipintura”, t. 1, Saggi, ed. A. Tomei, Milano 2009, s. 332-334, il. s. 333.

74. A. E. Nichols, Seeble Sings..., dz. cyt., s. 30-31; A. Ziemba, Sztuka Burgundii $i$ Niderlandów 1380-1500, t. 2, Niderlandzkie malarstwo tablicowe 1430-150o, Warszawa 2011, s. 283-286, il. 319; L. Campbell, "The Seven Sacraments”, dz. cyt., s. 137-145; 


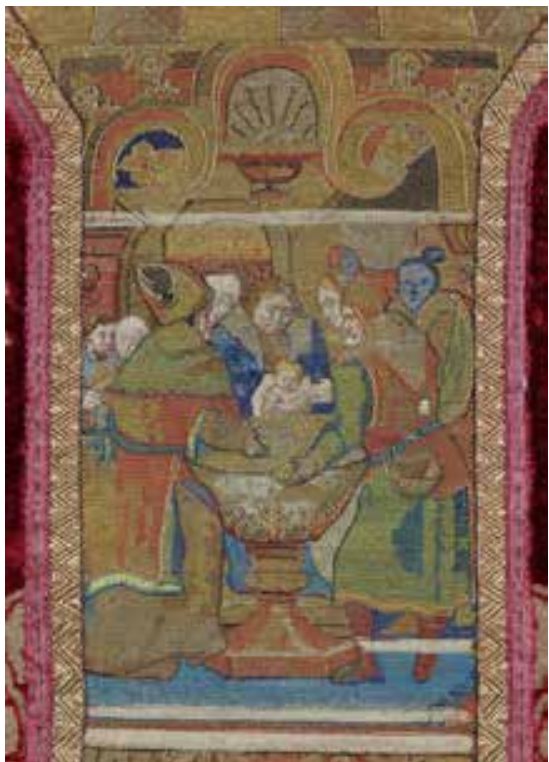

8. Chrzest, fragment tyłu ornatu z tzw. kompletu żywieckiego (fot. ks. P. Guzik) niegdyś na krzyżu, staje się każdorazowo rzeczywistą esencją liturgii ołtarza"75. Podobne rozwiązanie zastosował naśladowca Rogera van der Weydena lub niezależny Mistrz Alegorii Zbawienia z Prado (Vrancke van der Stockt?) w części centralnej Tryptyku Zbawienia z Ukrzyżowaniem, Wygnaniem z Raju i Sadem Ostatecznym z lat 1455-1459 (Madryt, Museo del Prado) ${ }^{76}$. Także w tym przypadku w centrum kompozycji została umieszczona grupa Ukrzyżowania, niejako na progu monumentalnego portalu otwierającego się na nawę główną gotyckiego kościoła. Sześć sakramentów (bez Eucharystii, którą wyobraża Ukrzyżowanie Chrystusa), zostało ukazanych jako naturalistyczne sceny umieszczone na kamiennych konsolach pod baldachimami portalowych ościeży. W ten sam sposób przedstawiono sześć scen cyklu pasyjnego na archiwolcie portalu. W zbliżonej konwencji rozmieszczano sakramenty wokół sceny Ukrzyżowania w rzeźbionych flamandzkich retabulach pasyjnych, powstających od końca wieku XV do lat 30. wieku XVI (np. Retabulum pasyjne z lat 1510-1520, katedra Saint-Jean Bois-le-Duc; Retabulum pasyjne ze scenami z legendy św. Tomasza Becketa z lat 1515-1520, kościół ewangelicki w Waase auf Ummanz; Retabulum pasyjne z początku XVI w., Paryż, Musée National du Moyen Âge, Hôtel Cluny, nr inw. Cl. 11923) ${ }^{77}$.

Szczególne miejsce w tej grupie przedstawień zajmuje dwustronna miniatura zdobiąca angielski manuskrypt teologiczno-dewocyjny Yokishire Carthusian Religious Miscellany z około 1470 roku (Londyn, British

75. A. Ziemba, Sztuka Burgundii i Nidrlandów 1380-150o, t. 2, Niderlandzkie malarstwo..., dz. cyt., s. 285.

76. A. E. Nichols, Seeble Sings..., dz. cyt., s. 32; A. Ziemba, Sztuka Burgundii i Nidrlandów 138o-150o, t. 2, Niderlandzkie malarstwo..., dz. cyt., s. 534-536, il. 712.

77. Por. Les retables anversois XV-XVI siècles, t. 1, Catalogue, ed. H. Nieuwdorp, Antwerpen 1993, s. 52-57, il. s. 53, s. 64-69 , il. s. 65; A. E. Nichols, Seeble Sings...,dz. cyt., s. 32-35, il. 18; 
Library, Ms. Add. 37049, fol. 27v-28), gdzie w górnej części obu kart nad alegorycznymi odniesieniami do tajemnicy zbawienia i potępienia umieszczono w górnym pasie Chrystusa Ukrzyżowanego, górującego nad przedstawionymi siedmioma sakramentami (brakuje spowiedzi świętej), które za pomocą linii są połączone $\mathrm{z}$ otwartą raną w boku Zbawiciela ${ }^{78}$. W ten sposób bardzo wyraźnie wskazano na źródło siedmiu znaków zbawienia. Ukrzyżowanie mogło być np. połączone tylko z jednym sakramentem, jak wyobraża to chociażby zdobienie inicjału D w traktacie Dirca van Delf Tafel van den Kersten z ok. 1405-1410 (Pierpont Morgan Library, M. 691, f. 18), gdzie pod krucyfiksem z naturalistycznie malowanym Chrystusem przedstawiono scenę bierzmowania ${ }^{79}$.

Nierzadko scenę Ukrzyżowania zastępowano innym wyobrażeniem odnoszącym się bezpośrednio do ofiary Chrystusa. Na wspomnianym już piętnastowiecznym kapturze kapy Giacoma de Romont (Berno, Bernisches Historisches Museum, nr inw. 308) zamiast Ukrzyżowania zaprezentowano Tron Łaski w typie Pietas Patris ${ }^{80}$, motyw niezwykle popularny w dewocyjnych przedstawieniach niderlandzkich z tego czasu, o wyraźnym charakterze pasyjnym, ale równocześnie i eucharystycznym ${ }^{81}$. Dlatego też wspomniane przedstawienie dopełniono umieszczonymi obok dwiema scenami - celebracją mszy świętej oraz przyjmowaniem komunii. W teologicznym ujęciu wszystkie trzy wyobrażenia mogą się zawierać w scenie Ostatniej Wieczerzy.

Spotykamy także przedstawienia, gdzie Chrystusa Ukrzyżowanego zastępowało wyobrażenie Męża Boleści (Vir Dolorum) w tłoczni mistycznej, co w powiązaniu z ilustracją siedmiu sakramentów ukazano na karcie anonimowego dzieła ascetyczno-dewocyjnego z wieku XV Spigiel des lidens Christi (Colmar, Stadtbibliothek, Cod. 306, fol. 1r.) ${ }^{82}$. Szczególny związek Vir Dolorum z sakramentami na miniaturze został podkreślony za pomoca

78. A. E. Nichols, Seeble Sings..., dz. cyt., s. 52-55, il. 20.

79. A. E. Nichols, Seeble Sings..., dz. cyt., s. 23, 28, il. 11.

80. T. Kruszyński, Ornat i dalmatyki..., dz. cyt., s. 20-22, il. 74-77; A. E. Nichols, Seeble Sings..., dz. cyt., s. 40-41, il. 19.

81. Zagadnienie to szeroko omawiają m.in. E. Panofsky, Imago Pietatis. Przyczynek do historii typów przedstawieniowych Mąż Boleści i Maria Pośredniczka, w: Erwin Panofsky - Studia z historii sztuki, opr. J. Białostocki, Warszawa 1971, s. 94-121; W. Mersmann, Schmerzensmann, w: Lexikon der christlichen Ikonographie, t. 4, Allgemeine Ikonographie $S-Z$, dz. cyt., kol. 87-95; G. Jurkowlaniec, Chrystus Umęczony. Ikonografia w Polsce od XIII do XVI wieku, Warszawa 2001.

82. A. E. Nichols, Seeble Sings..., dz. cyt., s. 23, 27-28, il. 12. 
czerwonych linii łączących je z tłocznią mistyczną. To samo rozwiązanie zostało powtórzone na niedawno odkrytym malowidle ściennym z ok. roku 1500 na sklepieniu prezbiterium kościoła św. Jakuba Większego w czeskim Pomezí nad Ohří, gdzie obok Chrystusa w tłoczni mistycznej z lewej strony zachowało się przedstawienie Chrztu, Bierzmowania, Spowiedzi i Namaszczenia chorych, z prawej zaś Kapłaństwa i Małżeństwa ${ }^{83}$. W obu przypadkach udzielanie sakramentów zostało zredukowane tylko do głównych postaci, ale z zachowaniem ich tradycyjnego układu ikonograficznego.

Tenże Chrystus Bolesny mógł też występować jako Vir Dolorum prezentujący swoje rany, co widać np. na drzeworycie umieszczonym na verso karty tytułowej otwierającej dzieło Confutatio apologetici cuiusda[m] sacre scripture falso inscripti Hieronymusa Dungersheima von Ochsenfurt (Lipsk, Wolfgangus Monacensis [Stoeckel] 1514) ${ }^{84}$. W górnej części widnieje centralnie umieszczona postać Chrystusa (Vir Dolorum) jako źródło sakramentów, wśród których - zgodnie z częstym wówczas schematem - wyróżniono Eucharystię wyobrażoną jako hostię w wieżycowej monstrancji. Bezpośredni związek kolejnych sakramentów z ranami Chrystusa podkreślono liniami łączącymi przebity bok Zbawiciela z kilkupostaciowymi scenami.

Jednakże iluminacja ukazująca siedem sakramentów $(27 \times 21 \mathrm{~cm})$ z ok. roku 1500, ujęta w ramki i przytwierdzona pierwotnie jako dekoracja szafki zakrystyjnej w dawnym konwencie Augustianek Potterie w Brugii (Brugia, Museum Onze-Lieve-Vrouw-Ter-Potterie), świadczy, iż mogły zachodzić transformacje dotychczasowych przedstawień ${ }^{85}$. W tym przypadku, wzorując się na układzie niderlandzkich retabulów z przełomu wieku XV i XVI, iluminator w części centralnej zilustrował moment przyjmowania komunii świętej przez klęczącą mniszkę. Za kapłanem ukazano ołtarz, na którym dwaj aniołowie podtrzymują wieżycową monstrancję z promieniującą hostią, ponad którą pod rozpiętym baldachimem jaśnieje niewielki krucyfiks. Dodatkowo na tle zwieńczenia baldachimu wyobrażono gołębicę w promienistej glorii jako symbol Ducha Świętego. Po bokach,

83. Zob. J. Royt, Středověké deskové a nástěnné malírství na Chebsku, w: Umění gotiky na Chebsku. Gotické umění na území historického Chebska a sbírka gotického sochařství Galerie Výtvarného Umění v Chebu, Cheb 2009, s. 83-87, il. 17-18.

84. G. Jurkowlaniec, "Typus Ecclesiae catholicae” - trydencka wizja Kościoła, jej geneza i recepcja, w: Sztuka po Trydencie, red. K. Kuczman, A. Witko, Kraków 2014, s. 29, il. 5 .

85. A. E. Nichols, Seeble Sings..., dz. cyt., s. 47-48, il. 15 . 
w wydzielonych malowanych ramach, przedstawiono sześć pozostałych sakramentów. Z lewej Chrzest, Bierzmowanie i Spowiedź, a z prawej Małżeństwo, Kapłaństwo i Ostatnie namaszczenie.

Omówiony bogaty kontekst sposobu ukazywania siedmiu sakramentów w wystarczający sposób tłumaczy obecność sceny Ostatniej Wieczerzy na ornacie z kompletu żywieckiego [il. 5]. Bezsprzecznie należy widzieć w niej bezkrwawą partycypację zbawczej ofiary Chrystusa, która w zamyśle twórcy całego programu wyraża najważniejszy sakrament, będąc równocześnie źródłem pozostałych. Wydarzenie z Wieczernika można także bez żadnych wątpliwości odnieść do sakramentu kapłaństwa, ustanowionego podczas Ostatniej Wieczerzy w przeddzień męki Chrystusa. Taka interpretacja akcentuje równocześnie rolę Kościoła instytucjonalnego jako depozytariusza łaski Boskiej, którą człowiek zyskuje przyjmując sakramenty święte.

Na zakończenie należy postawić pytanie, dlaczego w całym zespole tak dobitnie (obok Ostatniej Wieczerzy) wyróżniono Komunię święta i Spowiedź (na tabulach dalmatyk) [il. 5-7]. By móc na nie odpowiedzieć, trzeba przypomnieć bogaty kontekst religijno-społeczny czasu, w którym paramenty powstały. Jak już to zostało powiedziane, wykonano je w kręgu sztuki niderlandzkiej. Same zaś Niderlandy stały się w wieku XV kolebką nowej formy religijności określanej powszechnie jako devotio moderna, zrodzonej w środowisku tamtejszego bogatego mieszczaństwa jako reakcja na formalizm praktyk zewnętrznych, przerost modlitwy liturgicznej oraz spekulacji teologicznej, co określano jako devotio antiqua ${ }^{86}$.

Szczególnym przewodnikiem dla chrześcijan starających się żyć według nowych zasad było popularne dzieło Tomasza a Kempis O naśladowaniu Chrystusa z ok. roku 1427, kreślące jasno i prosto główne rysy nowej pobożności ${ }^{87}$. Drugim poczytnym traktatem stało się medytacyjne Życie Chrystusa autorstwa Ludolfa z Saksonii, wyrosłe z odrodzenia kartuzjańskiego, także mające duży wpływ na kształtowanie życia europejskiego

86. Szeroko omawiają to zagadnienie m.in. S. Axsters, La spiritualité des Pays-Bas: l'évolution d'une doctrine mystique avec une liste des traductions françaises des auteurs néerlandais, Louvain-Paris 1948, s. 99-117; R. R. Post, The Modern Devotion. Confrontation with Reformation and Humanism, Leiden 1968.

87. Tomasz a Kempis, O naśladowaniu Chrystusa, red. W. Zakrzewski, Lublin 1986. 
mieszczaństwa ${ }^{88}$. W obu traktatach do głosu doszło przekonanie podkreślające w chrześcijańskim życiu wartość doskonalenia moralnego, które mogło się dokonać poprzez kształtowanie woli, wyakcentowanie prawa miłości, pokory i oderwania się od świata. Kładziono nacisk na rozwój pobożności indywidualnej, polegającej na codziennym praktykowaniu cnót i wypełnianiu własnych obowiązków w imię doskonałej miłości. Wzywano również do osobistej modlitwy w domowym zaciszu, a także, w oparciu o Ewangelię, do kontemplacji człowieczeństwa Jezusa Chrystusa, które stawało się wzorem do naśladowania. W rozwoju życia wewnętrznego podkreślano znaczenie uczuć i osobistego przeżycia, ze szczególnym naciskiem położonym na częste przyjmowanie sakramentów świętych - spowiedzi i komunii świętej ${ }^{89}$. Tomasz a Kempis częstej, właściwie przygotowanej i pobożnie przeżytej Komunii świętej poświęcił całą księgę czwartą swego dzieła (O Sakramencie Ołtarza $)^{90}$. Z mocą pisał w niej tak: „Tu zaś w Sakramencie Ołtarza jesteś obecny cały, Bóg mój, Człowiek Jezus Chrystus: stąd wyniesie każdy obfity owoc na wieczne zbawienie, ilekroć Cię przyjmie godnie i pobożnie [...] Ten Sakrament daje nam łaskę nadprzyrodzoną, przywraca duszy utraconą cnotę i odnawia jej piękno przez grzech zeszpecone"19. W dziele Tomasza a Kempis znajdujemy także cenną wskazówkę, która pozwala nam łączyć scenę Ostatniej Wieczerzy z ornatu żywieckiego z sakramentem kapłaństwa: „Kapłan, ubrany w święte szaty, zastępuje Chrystusa; w pokorze zanosić ma błagalne modły do Boga za siebie i za wszytek lud. Przed sobą i za sobą ma znak Krzyża Pańskiego, aby wciąż pamiętał o męce Chrystusowej. [...] Ma krzyż wyszyty za sobą, ażeby wszelkie przykrości, od innych sobie wyrządzone, znosił cierpliwie dla Boga"92.

Znamienne jest, iż prekursorem nowego nurtu w pobożności devotio moderna był piętnastowieczny dominikański kaznodzieja ze Strasburga

88. Por. R. R. Post, The Modern Devotion..., dz. cyt., s. 42-47, 107-108, 521-550; Historia Kościoła, t. 2., 6oo-15oo, red. M. D. Knowles, D. Obolensky, Warszawa 1988, s. $356-357$.

89. Zob. K. Górski, Uwagi o "Rozmyślaniach dominikańskich" na tle pradów religijnych XV i poczatku XVI w., "Średniowiecze" 2 (1965), s. 302-320; T. Dobrzeniecki, "Rozmyślania dominikańskie" na tle średniowiecznej literatury pasyjnej, w: Rozmyślania dominikańskie, t. 1, wyd. K. Górski, W. Kuraszkiewicz, Z. Rozanów, T. Dobrzeniecki, Wrocław-Warszawa-Kraków 1965, s. 39-42; R. R. Post, The Modern Devotion..., dz. cyt., s. 107-108; Historia Kościoła...,dz. cyt., s. 356-358.

90. Tomasz a Kempis, O naśladowaniu Chrystusa..., dz. cyt., s. 291-353.

91. Tomasz a Kempis, O naśladowaniu Chrystusa..., dz. cyt., s. 298-299.

92. Tomasz a Kempis, O naśladowaniu Chrystusa..., dz. cyt., s. 314. 
Jan Tauler (ok. 1300-1361) ${ }^{93}$. Jego Kazania ${ }^{94}$ nie tylko przygotowały właściwy grunt pod nową pobożność - apogeum popularności zyskały w wieku reformacji, kiedy powstał komplet żywiecki, znajdując szczególne uznanie nie tylko u katolików, ale także u samego Marcina Lutra, który widział w Taulerze swojego prekursora ${ }^{95}$. Wprawdzie Jan Tauler w swoich Kazaniach bezpośrednio nie odnosi się do siedmiu sakramentów, to jednak wiele miejsca poświęcił Eucharystii. W kazaniu 15b "In principio erat Verbum..." i kazaniu 17 "Quis vestrum habebit amicum..." dowodził rangi i ważności Najświętszego Sakramentu Ołtarza ${ }^{96}$. Z kolei w cyklu czterech kazań o Najświętszym Sakramencie Ołtarza (kazanie 30 "Qui manducat meam carnem, et bibit meum sanguinem, in me manet, et ego in illo...", kazanie 31 "Qui manducat meam carnem...", kazanie 32 "Scriptum est in Johanne: Caro mea vere est cibus, sanguis meus vere est potus..." i kazanie 33 "Caro mea vere est cibus, sanguis meus vere est potus... [sic!]") uczony dominikanin jeszcze raz gruntownie tłumaczy tajemnicę Eucharystii, a przede wszystkim nawołuje do systematycznej i częstej komunii świętej, przypominając, iż spowiedź oraz pokuta są najlepszym do niej przygotowaniem ${ }^{97}$.

Zatem za wyakcentowaniem na paramentach żywieckich Ostatniej Wieczerzy, jednoznacznie odnoszącej się do mszy świętej oraz kapłaństwa, a także przedstawieniem Komunii świętej i Spowiedzi stoją jednoznaczne argumenty teologiczno-duszpasterskie. Ich wyobrażenia miały wyraźny charakter katechetyczny dla wiernych uczestniczących w liturgii, podczas której paramenty były używane. Następne zaś wieki udowodniły, że ich przesłanie stało się ponadczasowe.

Jednocześnie trzeba pamiętać, iż komplet powstał w czasie, gdy w Europie Zachodniej krystalizowała się protestancka nauka o sakramentach, a przede wszystkim sposób podejścia do Eucharystii. Nowa interpretacja natury obecności Chrystusa w Eucharystii przez czołowych teologów protestanckich spowodowała odrzucenie jej kultu. Mimo szczególnej bliskości wobec dotychczasowej nauki Kościoła Marcina Lutra, który z racji

93. L. Gnädinger, Tauler Johannes $O P$, w: Lexikon des Mittelalters, t. 8, Stadt (Byzantinisches Reich) bis Werl, München 2002, kol. 506-508.

94. J. Tauler, Kazania, przekł. W. Szymona, Poznań 1985.

95. W. Szymona, Jan Tauler - kaznodzieja XIV wieku, w: J. Tauler, Kazania, przekł. W. Szymona, Poznań 1985, s. 14.

96. J. Tauler, Kazania, dz. cyt., s. 133 i 146.

97. J. Tauler, Kazania, dz. cyt., s. 226-260. 
przyjmowania rzeczywistej obecności Ciała i Krwi Chrystusa w chlebie i winie zalecał szacunek dla Eucharystii, zwolennicy Zwingliego, przyjmując jedynie symboliczną obecność Chrystusa w wieczerzy, zdecydowanie odrzucili jej kult. W tym względzie nauka Kalwina, choć złagodziła doktrynę Zwingliego, to jednak zanegowała sens adorowania Najświętszego Sakramentu Ołtarza, widząc w tym zabobon. Reformatorzy, odrzucając tradycyjną naukę o mszy jako ofierze, twierdzili, iż godzi ona w doktrynę o usprawiedliwieniu przez samą wiarę oraz że ustanowili ją ludzie, a nie Chrystus. Teza głosząca, że msza rozumiana jako ofiara niweczy prawdę o jedności, doskonałości, wystarczalności i niepowtarzalności ofiary krzyżowej Chrystusa, stała się podstawą do nowego spojrzenia na istotę siedmiu sakramentów, co w konsekwencji doprowadziło do ich zanegowania i odrzucenia ${ }^{98}$. Zatem wyakcentowanie w komplecie żywieckim Ostatniej Wieczerzy oraz Komunii świętej i Spowiedzi, ilustrujących główne prawdy wiary doktryny katolickiej, było istotnym głosem apologetycznym oraz artystyczną odpowiedzią na tezy głoszone przez reformację.

Uwzględniając zatem dotychczasowe badania nad kompletem żywieckim, korzystając z archiwalnej kwerendy oraz rozpatrując bogaty kontekst historyczno-ikonograficzno-teologiczny, który bez wątpienia ukształtował na wskroś renesansowe projekty haftów Lucasa van Leyden, przedstawiające siedem sakramentów, a także mistrzowskie wykonanie całego zespołu, należy stwierdzić, iż była to niezwykle kosztowna i bogata pod każdym względem fundacja artystyczna Komorowskich. Fundatorzy w ten sposób przyczynili się do podniesienia splendoru liturgii celebrowanej przez wieki w prowincjonalnym miasteczku, jakim był wówczas Żywiec. Równocześnie komplet żywiecki jest niespotykanym na tak wielką skalę świadectwem kultury religijnej w Małopolsce w pierwszych trzech dekadach wieku XVI.

98. Szerzej te zagadnienia omawiają m.in. J. Cadier, La doctrine calviniste de la Saint Cène, Montpellier 1951; H. Gollwitzer, Coena Domini. Die altlutherische Abendmahlslehre in ihrer Auseinandersetzung mit dem Calvinismus, dargestellt an der lutherischen Frühorthodoxie, München 1988; P. Bühler, Le confit des rèformateurs sur la sainte Cène. Quelques implications toujours actuelles, „Positions Luthéiennes" 27 (1979), s. 161-180. 


\section{Bibliografia}

Źródła

F. Augustin, Kroniki żywieckie od czasów zamierzchłych do 1845 roku, opr. S. Grodziski, Z. Jedynak, R. Kosiński, Z. Rączka, W. Zyzak, Żywiec-Kraków 2007.

AV 16 - Visitatio ecclesiarum decanatuum Zathoriensis et Oswiecimensis et Zywecensis per Perillustrem olim R[evere]ndum Dominum Remigium Suszycki, can[oni]cum Cra[coviensem], specialiter deputatum, anno 1707-17og expedita et peracta, Archiwum Kurii Metropolitalnej w Krakowie.

AV 34 - Summarium seu descripto status ecclesiarum, omnium parochorum korundem in decanatu Zyvecensis consistentium ex speciali mandato Celsissimi Illustrissimi et Reverendissimi Domini, D[Omi]ni Andrea Stanislai Kostka in Załuskie Załuski, Dei et Apostolicae Sedis episcopi Cracoviensis, ducis Severiae, per me Antonium Franciscum de Brzezie Lanckoronski, canonicum Gnesnensem, praepositum Osvecimensem, anno D[omi]ni millesimo septingentesimo quadragesimo octavo, visitatorum hoc in volumine comprehensum, Archiwum Kurii Metropolitalnej w Krakowie.

AV 58 - Acta visitationis generalis decanatuum Zyvecencensis et Osviecimensis in conformitate diplomaticae dispositionis ab Excell[sisi]mo Ill[ustrissi]mo et R[everendisssi]mo Domino Floriano Amando de Janowek Janowski Episcopo Tarnovensi, Sacrae Caes[are]o-Regiae Ma[iesta]tis consiliario ad 20 maji anni curen[tis] in personam infrapecificati delegati visitatoris gratiose emandatae quae 1 mo tabellas personarum ecclesticarum in iisdem decanatibus reperibilium, 2do prothocollum ecclesiarum, necnon 3 tio ibellos supplices quorumdam parochianorum sub aetate visitationis porectos continent. Anno 1792, Archiwum Kurii Metropolitalnej w Krakowie AVCap nr 17 - Acta visitationis exterioris Decanatuum Osviencimensis Novi Montis Zatoriennsis et Skavinensis ad Archidiaconatum 
Crac. Pertinentium [...] a. D. 1598, Archiwum Kurii Metropolitalnej w Krakowie.

AVCap 46 - Visitatio Oswicimensis Decanatus a Perill[ust]ri ac

Reverendissimo Domino Nicolao Oborski Dei et Apstolicae Sedis

Gra[ti]ae Episcopo Laodicen[sis], Sufraganes, Archdiacono et Oficiali

Generali Cracoviensi Anno D[omi]ni MDCLVIII Die XX Novembris, inhoata et subseguentibus diebus peracta, Archiwum Kurii

Metropolitalnej w Krakowie.

Breviarium fidei. Wybór doktrynalnych wypowiedzi Kościoła, red. S. Głowa,

I. Bieda, Poznań 1997.

Dokumenty soborów powszechnych. Tekst grecki, łaciński, arabski, ormiański, polski, t. III, (1414-1445) Konstancja, Bazylea-Ferrara-Florencja-Rzym, opr. A. Baron, H. Pietras, Kraków 2007.

Dokumenty soborów powszechnych. Tekst łaciński, polski, t. IV/1, (1511-1870), Lateran V, Trydent, Watykan I, opr. A. Baron, H. Pietras, Kraków 2007.

Tomasz a Kempis, O naśladowaniu Chrystusa, red. W. Zakrzewski, Lublin 1986.

A. Komoniecki, Chronografia albo Dziejopis żywiecki, opr. S. Grodziski, I. Dwornicka, Żywiec 1987.

J. Tauler, Kazania, przekł. W. Szymona, Poznań 1985.

\section{Opracowania}

R. Alcoy, La ricezione della pittura giottesca in Spagna, dai Bassa a Starnina, w: Giotto e il Trecento "Il più Sovrano Maestro stato in dipintura", t. 1, Saggi, ed. A. Tomei, Milano 2009, s. 321-335.

S. Axsters, La spiritualité des Pays-Bas: l'évolution d'une doctrine mystique avec une liste des traductions françaises des auteurs néerlandais, Louvain-Paris 1948.

B. Biedrońska-Słota, Ornat i dwie dalmatyki (II/207), w: Wawel 10oo-20oo. Skarby archidiecezji krakowskiej, t. 2, Katalog, red. J. A. Nowobilski, Kraków 2000, s. 216-217.

P. Bühler, Le confit des rèformateurs sur la sainte Cène. Quelques implications toujours actuelles, "Positions Luthéiennes" 27 (1979), s. $161-180$.

J. Cadier, La doctrine calviniste de la Saint Cène, Montpellier 1951. 
L. Campbell, The Seven Sacraments, w: Roger van der Weyden in Context.

Papers presented at the Seventeenth Symposium for the Study of Underdrawing and Technology in Painting held in Leuven, 22-24 October 20og, ed. by L. Campbell, J. Van der Stock, C. Reynolds, L. Watteeuw, Paris-Leuven-Walpole, MA 2012, s. 137-146.

A. Capitanio, Casula a campana, w: San Nicola. Splendori d'arte d'Oriente e d'Occidente, ed. M. Bacci, Milano 2006, s. 328-329.

Das Tausendjährige St. Blasien 2oojähriges Domjubiläum, Hrsg. Ch. Römer, t. 1, Katalog, Karlsruhe 1983.

T. Dobrzeniecki, "Rozmyślania dominikańskie” na tle średniowiecznej literatury pasyjnej, w: Rozmyślania dominikańskie, t. 1, red. K. Górski, W. Kuraszkiewicz, Z. Rozanów, T. Dobrzeniecki, Wrocław-Warszawa-Kraków 1965, s. 39-42.

Flanders in the Fifteenth Century: Art and Civilization, Catalogue of the Exhibition: Masterpieces of Flemish Art: Van Eyck to Bosch, ed. by R. Edgar, P. Coremans Detroit-Bruges 1960.

G. Gagliardi, M. Piccinini Fabi, Il piviale di Ascoli, Ascoli Piceno 1990.

A. Galli, The Fortune of the Pollaiuolo Brothers, w: Antonio and Piero del Pollaiuolo - "Silver and Gold, Painting and Bronze...", ed. by A. Di Lorenzo, A. Galli, Milano 2014, s. 25-78.

L. Gnädinger, Tauler Johannes OP, w: Lexikon des Mittelalters, t. 8, Stadt (Byzantinisches Reich) bis Werl, München 2002, kol. 506-508.

H. Gollwitzer, Coena Domini. Die altlutherische Abendmahlslehre in ihrer Auseinandersetzung mit dem Calvinismus, dargestellt an der lutherischen Frühorthodoxie, München 1988.

K. Górski, Uwagi o "Rozmyślaniach dominikańskich" na tle prądów religijnych XV i początku XVI W., "Średniowiecze“ 2 (1965), s. 302-320.

Historia Kościoła, t. 2,6oo-15oo, red. M.D. Knowles, D. Obolensky, Warszawa 1988.

Ch. A. Isermeyer, Beschneidung Christi, w: Lexikon der christlichen Ikonographie, t. 1, Allgemeine Ikonographie A-E, Hrsg. E. Kirschbaum, Rom-Freiburg-Basel-Wien 1994, kol. $271-273$.

G. Jurkowlaniec, Chrystus Umęczony. Ikonografia w Polsce od XIII do XVI wieku, Warszawa 2001.

G. Jurkowlaniec, "Typus Ecclesiae catholicae" - trydencka wizja Kościoła, jej geneza i recepcja, w: Sztuka po Trydencie, red. K. Kuczman, A. Witko, Kraków 2014, s. 23-38. 
B. Kalfas, Ornat i dalmatyki z tzw. kompletu żywieckiego, w: Polonia tesoros y colecciones artísticas. 1 junio - 4 septiembre 2011 Palacio Real de Madrid, ed. B. Biedrońska-Słota, Patrimonio Nacional, Muzeum Narodowe w Krakowie 2011, s. 78-79.

B. Kerber, Sakramente, w: Lexikon der christlichen Ikonographie, t. 4, Allgemeine Ikonographie $S-Z$, Hrsg. E. Kirschbaum, Rom-Freiburg-Basel-Wien 1994, kol. 5-11.

F. Kopera, Muzeum Narodowe w Krakowie. Wybór i opis cenniejszych zabytków, Kraków 1923.

N. Krupa, Włoskie tkaniny aksamitne z XVi XVI wieku w zabytkowych tekstyliach ze skarbca katedry na Wawelu, Kraków 2013.

T. Kruszyński, Ornat i dalmatyki z Żywca i ich holandzkie pochodzenie, Kraków 1927.

T. Kruszyński, Skarbiec katedry wawelskiej i Muzeum Metropolitalne, z. 6, Ornat Piotra Kmity i ołtarz św. Antoniego fundacji Kmitów w Katedrze wawelskiej, Kraków 1930.

Les retables anversois XV-XVI siècles, t. 1, Catalogue, ed. H. Nieuwdorp, Antwerpen 1993.

E. Lucchesi Palli, L. Hoffscholte, Darbringung Jesu im Tempel, w: Lexikon der christlichen Ikonographie, t. 1, Allgemeine Ikonographie A-E, Hrg. E. Kirschbaum, Rom-Freiburg-Basel-Wien 1994, kol. 473-477.

L. Martini, Il piviale in "opus anglicanum" di Pio II, w: Il piviale di Pio II, ed. L. Martini, Milano 2001, s. 15-25.

L. Martini, Il piviale di Pienza e i rapporti con la cultura artistica del Trecento, w: Il piviale di Pio II, ed. L. Martini, Milano 2001, s. 26-36.

L. Martini, Il programma iconografico, w: Il piviale di Pio II, red. L. Martini, Milano 2001, s. 37-66.

Museum Schnütgen. Die liturgischen Gewänder 11. bis 19. Jahrhundert, Hrsg. G. Sporbeck, Köln 2001.

B. Nadolski, Leksykon liturgii, Poznań 2006.

A. E. Nichols, Seeble Sings: Iconography of the Seven Sacraments 1350-1544, Oxford 1997.

M. Piwocka, Arrasy z groteskami, w: J. Szablowski, A. Misiąg-Bocheńska, M. Hennel-Bernasikowa, M. Piwocka, Arrasy wawelskie, Warszawa 1999, s. 296-348.

R. R. Post, The Modern Devotion. Confrontation with Reformation and Humanism, Leiden 1968. 
J. Royt, Středověké deskové a nástěnné malírství na Chebsku, w: Umění gotiky na Chebsku. Gotické umění na území historického Chebska a sbírka gotického sochařství Galerie Výtvarného Umění v Chebu, Cheb 2009, s. 67-87.

F. Siddi, Workshop of Antonio del Pollaiuolo "Zachariah Leaving the Temple", secondo half of the fifteenth century, w: Antonio and Piero del Pollaiuolo - "Silver and Gold, Painting and Bronze...", ed. by A. Di Lorenzo, A. Galli, Milano 2014, s. 182-183.

F. Siddi, Embroidery in silk and gold thread Florence, Museo dell'Opera di Santa Maria del Fiore, w: Antonio and Piero del Pollaiuolo - "Silver and Gold, Painting and Bronze...", ed. A. Di Lorenzo, A. Galli, Milano 2014, s. 184-191.

H. J. de Smedt, De Antwerpse retabeles en hun iconografie: een overzicht van onderwerpen en veranderingen, w: Les retables anversois XV-XVI siècles, t. 2, Essays, ed. H. Nieuwdorp, Antwerpen 1993, s. 23-46.

W. Szymona, Jan Tauler - kaznodzieja XIV wieku, w: J. Tauler, Kazania, przekł. W. Szymona, Poznań 1985, s. 5-41.

Zabytki sztuki w Polsce. Inwentarz topograficzny, t. 3, Powiat żywiecki.

Województwo krakowskie, red. J. Szablowski, Warszawa 1948.

A. Ziemba, Sztuka Burgundii i Niderlandów 138o-15oo, t. 1, Sztuka dworu burgundzkiego oraz miast niderlandzkich, Warszawa 2008.

A. Ziemba, Sztuka Burgundii i Nidrlandów 138o-15oo, t. 2. Niderlandzkie malarstwo tablicowe 1430-150o, Warszawa 2011. 


\title{
Abstract
}

\author{
Ks. Szymon Tracz \\ A visible sign of invisible grace. The so-called Żywiec \\ ensemble in the treasury of the Wawel Cathedral in light \\ of source and iconographic studies
}

\author{
Keywords: \\ chasuble, liturgical \\ vestments, \\ embroidery, \\ brocade, seven \\ sacraments, \\ sacrament, \\ christening, \\ confirmation, \\ Holy Communion, \\ anointing of the \\ sick, penance, \\ holy orders, \\ matrimony, devotio \\ moderna, sign, \\ grace, reformation, \\ Lucas van Leyden, \\ Żywiec, Krakow \\ cathedral.
}

An exceptional place among liturgical vestments in the Treasury of the Wawel Cathedral occupies an ensemble consisting of a chasuble and two dalmatics, referred to as the 'Żywiec ensemble' (Treasury of the Wawel Cathedral, chasuble - inv. no. KKK tk/334, a dalmatic depicting the Holy Communion - KKK tk/334A, a dalmatic depicting the Confession - KKK 334B). The vestments were sewn from Italian brocade around 1525 in Flanders and ornately decorated with figurative embroidery according to a design attributed to Lucas van Leyden (d. 1533). Since 1598 archival sources explicitly link the Żywiec ensemble to the parish church of the Nativity of the Blessed Virgin Mary in Żywiec (currently the co-cathedral of the Bielsko-Biała/Żywiec diocese), which precludes the possibility of a later transfer or any purchase of the ensemble.

The exceptional character of the vestments from Żywiec is emphasized by implementation of an ideological programme referring to the administration of the holy sacraments. Only a few examples of European liturgical vestments decorated with images of the seven sacraments are extant - e.g. in St. Vincent Collegiate Church in Soignies (Zinnik) from late 15th century, on the band of a no longer extant cope of 1470 founded by count Giacomo de Savoia-Romont (Bern, Bernisches Historisches Museum, inv. 308), on embroideries of a Flanders cope from the end of the 15th century (Detroit, Institute of Arts), although we may encounter instances of such images in other fine arts, in particular in 15th century Dutch art: wall paintings, stained-glass paintings, book illustrations, sculptures (esp. font decorations) or many surviving sculpted or painted altarpieces and tapestries.

The ensemble features a sacramental cycle split between three items, i.e. the chasuble and the two dalmatics. Due to the split, its entirety was visible only when used during the liturgy by three clerics: a priest and two deacons. In terms of iconography, the images depicting the administration 
of sacraments derive from a wealth of iconographic tradition determining the manner in which the subsequent sacrament is shown, based on a previously developed iconographic type, which was then expanded by the inclusion of additional characters or by introducing unique details taken from everyday observation of liturgical and religious life. The departure point for constructing individual compositions is an easily recognisable 'visible sign' constituting the next scene, behind which hides the content referring to 'invisible grace' specific to each sacrament. The fact that such set of embroidered images, rich in ideological content, was created must be linked to a vivid 15th century trend referred to as devotio moderna and apologetic content in the context of Martin Luther's reformation movement after 1517, which renounced the Churche's teachings of the seven sacraments. 


\section{Abstrakt}

Ks. Szymon Tracz

Widzialny znak niewidzialnej łaski. Tzw. komplet żywiecki

w skarbcu katedry na Wawelu w świetle badań źródłowych

i ikonograficznych

\author{
Słowa kluczowe: \\ ornat, dalmatyka, \\ paramenty \\ liturgiczne, haft, \\ altembas, siedem \\ sakramentów, \\ sakrament, \\ chrzest, \\ bierzmowanie, \\ Komunia św., \\ namaszczenie \\ chorych, pokuta, \\ kapłaństwo, \\ małżeństwo, \\ devotio moderna \\ znak, łaska, \\ reformacja, Lucas \\ van Leyden, \\ Żywiec, katedra \\ krakowska,
}

Wyjątkowe miejsce wśród tkanin liturgicznych przechowywanych w skarbcu katedry na Wawelu zajmuje garnitur składający się z ornatu i dwóch dalmatyk, określany jako tzw. komplet żywiecki (ornat - nr inw. KKK tk/334, dalmatyka ze sceną Komunii świętej - KKK tk/334A, dalmatyka ze sceną Spowiedzi - KKK 334B). Paramenty uszyto z włoskiego altembasu ok. 1525 r. we Flandrii i bogato ozdobiono haftami figuralnymi według projektu atrybuowanego Lucasowi van Leyden (zm. 1533). Źródła archiwalne jednoznacznie wiążą komplet żywiecki od 1598 r. z kościołem parafialnym Narodzenia NMP w Żywcu (obecnie konkatedra diecezji bielsko-żywieckiej), co wyklucza możliwość jego późniejszego przekazania lub też ewentualnego odkupienia.

Wyjątkowość paramentów z Żywca podkreśla program ideowy nawiązujący do udzielania sakramentów świętych. Z terenu Europy zachowało się tylko kilka przykładów dekorowania tkanin liturgicznych przedstawieniami siedmiu sakramentów - np. w kolegiacie St. Vincent w Soignies (Zinnik) z końca XV w., na borcie z niezachowanej kapy z około 1470 r. fundacji hrabiego Giacoma de Savoia-Romont (Berno, Bernisches Historisches Museum, inv. 308), na haftach z flandryjskiej kapy z koń. XV w. (Detrorit, Institute of Arts), mimo iż spotykamy realizacje takich przedstawień w innych sztukach plastycznych, zwłaszcza w kręgu piętnastowiecznej sztuki niderlandzkiej - malarstwie ściennym, witrażowym, książkowym, rzeźbie (głównie w dekoracji chrzcielnic) czy też licznie zachowanych rzeźbionych lub malowanych retabulach ołtarzowych oraz na tapiseriach.

Na omawianym komplecie cykl sakramentalny rozdzielono pomiędzy trzy obiekty - ornat i dwie dalmatyki, dzięki czemu był on widoczny w całości tylko wtedy, gdy używało go podczas liturgii trzech duchownych - kapłan i dwóch diakonów. Pod względem ikonograficznym przedstawione sceny udzielania sakramentów czerpią z bogatej tradycji 
określającej sposób ukazywania kolejnego sakramentu w oparciu o wcześniej wpracowany typ ikonograficzny, który następnie był rozbudowywany przez dodawanie dodatkowych postaci lub też za pomocą wprowadzania charakterystycznych szczegółów czerpanych z codziennej obserwacji życia liturgiczno-religijnego. Punktem wyjścia do budowania poszczególnych kompozycji jest łatwo rozpoznawalny „widzialny znak”, konstytuujący kolejną scenę, za którym kryje się treść odnosząca się do "niewidzialnej łaski" właściwej dla poszczególnych sakramentów. Powstanie tak bogatego w treści ideowe zespołu haftowanych przedstawień należy wiązać z żywym piętnastowiecznym nurtem określanym jako devotio moderna oraz treściami apologetycznymi w kontekście ruchu reformacyjnego Marcina Lutra po roku 1517, negującego naukę o siedmiu sakramentach Kościoła. 
